Article

\title{
Morphotectonic analysis of the Upper Guajira, Colombia. A GIS and Remote Sensing approach
}

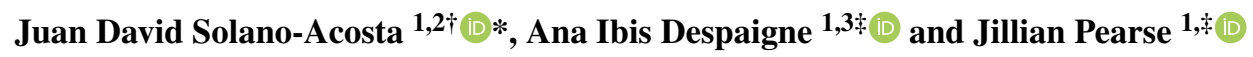 \\ 1 Universidad de Los Andes, Geosciences Department, Bogotá 111711, Colombia; jdsolano10@ uniandes.edu.co (J.D.); \\ ai.despaigne@uniandes.edu.co (A.I.); j.pearse@uniandes.edu.co (J.P.) \\ 2 Universidad de Granada, Granada 18071, Spain; jdsolano10@correo.ugr.es \\ 3 aigeodynamics, 42a Phoenix St, Dianella, Perth, Western Australia, 6059 ; aigeodynamics@ gmail.com \\ $\dagger$ Corresponding author \\ $\ddagger$ These authors contributed equally to this work.
}

\begin{abstract}
This study uses Landsat 8 and Digital Elevation Models (DEM) to show the dominant orientations of digital lineaments and morphotectonic features between measured trends and the tectonic evolution of the Upper Guajira, Colombia, in the northernmost region of the South American plate. Data from Landsat-8 and hillshaded images of three Digital Elevation Model (DEM) images with different resolutions (SRTM: 90m, ASTER-GDEM: $30 \mathrm{~m}$ and Alos-Palsar: $12.5 \mathrm{~m}$ ), were used for the extraction and mapping of morpholineaments, drainage network and morphological features. Lineaments were analyzed by means of north azimuth frequency, length, density distributions, lithological distributions and geochronological periods. Tectonic control was supported by using the digitized geological map created by the Colombian Geological Service (SGC). Lineaments and faults were analyzed through the interpretation of a Riedel shear model as a result of the transtensional/transpressional tectonic arrangement of the Caribbean and South American plates. The directional trends of lineaments and faults indicate two dominant directions: NE-SW and E-W. The azimuth distribution analysis of measured structures and drainage channels show similar trends, except for some differences in the predominant directions of some drainage channels. The similarity in the orientation of lineaments, faults and drainage system highlights the degree of control exerted by underlying structures on the surface geomorphological features. Drainage channel classification illustrates the morphological and neo-tectonic complexity of the region. The extracted lineaments were divided into five geochronological groups based on the main ages of host rock formations according to the Colombian Geological Service (SGC) geological map. From the Cretaceous onward, the lineament azimuth frequency rotates from a NE-SW trend to a prominent E-W direction, which resembles the translation that Caribbean plate has been undergoing since the Cretaceous. Our results confirm that Remote Sensing techniques are reliable and useful to study the morphotectonic of an area and can be applied to zones of difficult access.
\end{abstract}

Keywords: Remote sensing; Morphotectonic analysis; Lineaments; Riedel shear model; Upper Guajira; Caribbean plate.

\section{Introduction}

Northern South America has a long history of orogeny and sedimentary basin formation driven by the influence of the Caribbean, Nazca and South American plates [1-4]. The southwestern margin of the Caribbean plate is a wide zone of approximately $600 \mathrm{~km}$ at the northernmost limit of the Andes cordillera [5-12], and its evolution has been described as a complex interaction between different tectonic terranes bounded by major strike-slip, and thrust systems [13-15]. The Upper Guajira (Fig.1) is a geologically complex area in the northernmost tip of South America, which developed as a result of several deformation phases since the Proterozoic, presenting several distinct geologic, tectonic and morphologic features [9,16-20]. The most prominent feature of the study area is the Cuisa fault (CF), which is a high angle strike-slip fault with a right lateral displacement of approximately $15 \mathrm{~km}$, extending from west to east [21,22], and that has been related to a Late Cretaceous-Paleogene convergence event [20]. We identify previously unknown morphotectonic features of 
the Upper Guajira using optical satellite images, which provide clues to its complex tectonic history. Morphotectonic analysis consist of the identification and study of faults and/or fold systems, fracture systems and geological lineaments [23,24,24,25]. For this study we use a set of morphometric techniques based on analysis of satellite images. Drainage network analysis also contributes to the understanding of tectonic activity, since tectonic deformation is recorded in the flow path trends. This analysis helps in the identification of faults or fractures patterns and geomorphological anomalies [26-32]. A population of geological lineaments refers to a mappable linear or curvilinear feature over the Earth's surface, which can be expressions of faults, changes in topography or other linear zones of weakness [31]. Lineament mapping has become increasingly popular since geological mapping from aerial photographs began [32,33]. Furthermore, the processing and analysis of lineaments improves our understanding of neo-tectonics and structures [24,29,34]. The use of remote sensing facilitates the interpretation of an extensive area, which would be difficult to accomplish using field techniques. $[29,35,36]$. Since the middle of the last century many researches have focused their attention on the role that tectonics, especially neo-tectonics, has played in the geomorphological evolution of an area [28,37,38,40-42]. Several studies have shown that bedrock geometry deformations due to rock subsidence and/or uplift, along with extensional and compressional processes, causes perturbations in fluvial networks [29,39,42], so a drainage network, in relief and in plain geometry, highlights the interaction between surface processes and the propagation of faults and folds that have led to the formation of the tectonic arrangement in a determined region, since stream channels are easily affected by the type and orientation of geological structures. The study of the drainage network can therefore improve our understanding of the tectonic events experienced in the Upper Guajira.

Satellite images are widely used for fast identification, extraction, interpretation and mapping of lineaments, drainage networks and morphostructural features [24,29,32,34,43-45,47,48]. The rapid advances in Geographical Information Systems (GIS) has led to an easier identification and analysis of morphotectonic features. Two types of satellite data were used in this work: A multispectral Landsat 8 OLI/TIRS image and three Digital Elevation Model (DEM) images with different resolutions (SRTMx90m, ASTER-GDEMx30m and Alos Palsar $\mathrm{x} 12.5 \mathrm{~m}$ ). The processing and feature extraction were done using ArcGIS 10.5, ENVI5.3 and PCI Geomatica 2012 [24,29,49-51]. The aim of this study is to assess how a morphotectonic zone reflects the historical deformation stages, in this case over the arid Upper Guajira zone. This work has three main objectives (1) to show how modern techniques in satellite images analysis can reveal morphological features and the processes responsible for the landscape evolution over a large area, (2) to update the knowledge of the structural arrangement of the Upper Guajira resulting of various tectonic plates in historical and recent times, and (3) to make a basic, but a practical guide for this kind of analysis that could be applied elsewhere, especially in areas of difficult access .

\section{Geologic and tectonic settings}

The Upper Guajira region is located in the north of Colombia, over a peninsula at the northern tip of South America, presenting an area of $7640 \mathrm{~km}^{2}$ over an altitude of between 2 to and 840 m.a.s.l. and constitutes the northern continental zone of the Northern Andean Block (NAB) (Fig.1A), which is considered as a microplate comprising numerous parautochthonous and allochthonous plate fragments and tectonic slivers of continental, pericratonic and oceanic affinity, which have been tectonically mixed. The evolution of the mentioned tectonic mosaic and its physiographic expression is the result of the complex plate interaction beginning in the Proterozoic and including the Farallon (now extinct), Nazca, Caribbean and South American plates. NAB is located at the northwestern corner of South America and extends from north of the Huancabamba deflection in north in northern Peru, to the Caribbean, including the cordilleran regions of Ecuador, Colombia and Venezuela [11]. NAB in the Caribbean zone is the result of the interaction between the multiple plate boundaries and the transtensional-transpressional tectonics that have controlled the accretion of oceanic terrains to the continental South American margin [13,14,54-57]. The study area is bordered to the north and west by the Caribbean Sea, to the south by the Oca fault (OF) and by two mountain ranges, the "Sierra Nevada de Santa Marta" (SNSM) and the "Montes de Oca" which corresponds to the foothills of the Eastern Andean Cordillera in the Serrania of Perija (SP) [52,53]. The most prominent tectonic feature of the zone is the strike-slip CF (Fig.1B). The Upper Guajira is conformed by low altitude mountain ranges such as the Seranias of Carpintero, Simarua, Cosinas, Jarara and Macuira (Fig.1C). 

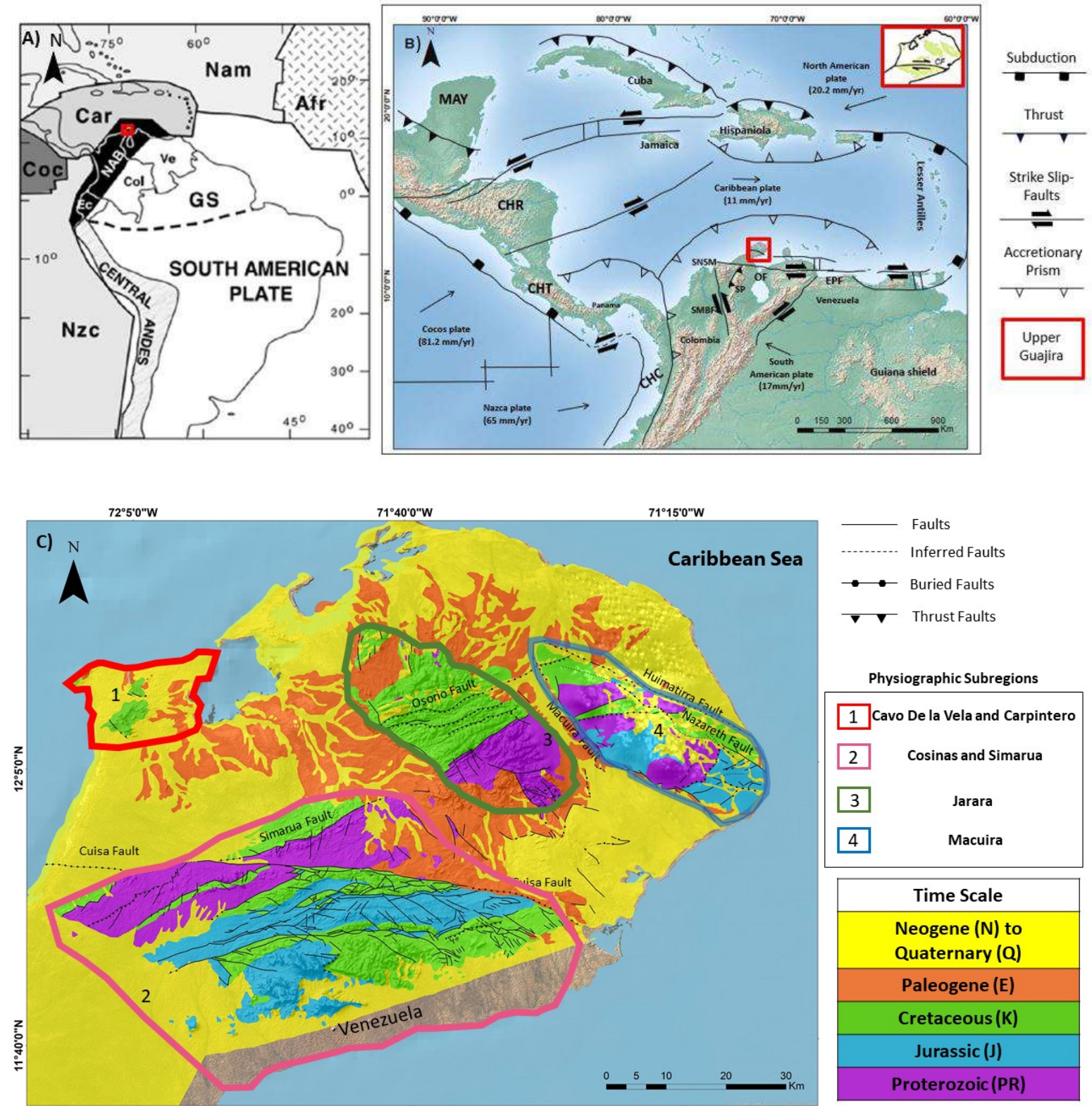

Figure 1. Regional tectonic setting between the Caribbean and South American plates and main tectonic features of the Upper Guajira region. A) Tectonic frame of South America. NAB=North Andean Block; Car=Caribbean Plate; Nzc=Nazca Plate; $\mathrm{Coc}=$ Cocos Plate; Nam=North American Plate; Afr $=$ African Plate; $\mathrm{GS}=$ Guyana Craton; Ec, $\mathrm{Col}, \mathrm{Ve}=$ Boundaries between Ecuador, Colombia and Venezuela (Modified from Cediel et al., 2002 [10]). B) Current tectonic map of the Caribbean area with movement rates of the different tectonic plates (Modified from Weber et al., 2011 [72] \& Quintero-Ortiz, 2017 [20]). SNSM: Sierra Nevada of Santa Marta, SMBF: Bucaramanga-Santa Marta Fault system, CF: Cuisa Fault, EPF: El Pilar Fault, OF: Oca Fault, MAY: Maya block, CHR: Chortis block, CHT: Chorotega block, CHC: Choco block. C) Generalized geologic map of the study area (red square in Figs. 1A) and 1B)) compiled and modified from Rodríguez and Londoño, 2002 [70]. Units were divided by its chronological period.

Three main collisional orogenesis and a period of regional taphrogensis affected the NAB before the initiation of the Northern Andean Orogeny (e.g. The mid-Proterozoic Grenville Orogeny, the mid-Ordovician-Silurian Quetame Orogeny, a Permo-Triassic Orogeny and a taphrogensis event referred as "Bolivar Aulacogen" after Triassic Orogeny $[13,58-60])$. The Andean orogeny started in the Cretaceous as a result of the subduction and convergence between the Caribbean and South American plates. The more recent theory asserts that the Caribbean Plate emerged from the Galapagos Hotspot, which sourced an oceanic plateau giving raised to a large 
igneous province (LIP), with a main magmatic pulse occurring $90 \mathrm{My}$ ago. This plate has been drifting toward the east until reaching its present position in relation to South American plate; motion that induced a significant strike-slip regime along its northern and southern boundaries (i.e. CF and OF; Fig.1B) [4,61]. The NW margin of South America is defined by a widespread region of oblique convergence and right lateral deformation. Locally, the oblique convergence of the Caribbean Plate gives rise to a regional transtenssive to transpressive tectonic events, which are recorded in discrete tectonic blocks along the San Jacinto belt, SP, SNSM and Upper Guajira, exposing similar lithotypes and structures of the Central Cordillera [3,62-64].

Two structural trends dominate the regional tectonic of the Guajira zone and a good portion of the northern part of South America: (1) A regional trend with N-S to NE-SW azimuth, present along the Andean Colombian Range, which rotates with a NE azimuth in Pailitas (Cesar department), a tendency observed until the Upper Guajira zone [73]; and (2) a structural trend with E-W to NW-SE azimuth composed of dextral strike-slip faults, which were very active during the early Eocene to Oligocene. E-W to NW-SE fault trends are thought to be younger than the regional system NE-SW and produce a movement that is related to the strike movement, which is responsible for the uplift, sinking and horizontal eastern displacement of the blocks that make up the different serranias (Fig.1C) [70,74,75]. Therefore, most of the tectonic complexity in the Guajira peninsula is related to the proximity of the dextral strike-slip $\mathrm{OF}$ and $\mathrm{CF}$ and is directly related to the transcurrent movements of those faults [76].

Four deformation events took place in the region: (1) Generation of Late Eocene half-grabens in the Upper Guajira, (2) opening of transtensive basins (e.g. Middle Guajira) with calcareous sedimentation during Eocene-Oligocene [77-80], (3) Early Miocene transtension [75] and (4) a Middle Cenozoic uplifting event of the Central Cordillera, SNSM and SP, the latter two being the source of the sediments deposited in this period over the nearby basins. These uplifts occurred due to a change from an extensional to a compressive regime, reactivating the $\mathrm{CF}$ and $\mathrm{OF}[14,79,81]$. Within this tectonic framework, the small mountain ranges from the study zone (e.g. Cosinas, Simarua, Jarara and Macuira; Fig.1C) in the Upper Guajira are formed by three lithostratigraphic belts which comprise from south to north: (1) a similar sequence of a Mesozoic weakly deformed volcano-sedimentary rocks found in SNSM and SP [65,66], (2) a granulite Grenvillian and Late Paleozoic to Triassic metamorphic succession intruded by Upper Jurassic plutons [67,68] and (3) an Upper Cretaceous belt of greenschist intercalated with mafic-ultramafic rocks. Cabo de la Vela is known as an ultramafic complex cropping out as isolated remnants, and the Carpintero serrania is composed of meta-sedimentary rocks, especially quartzites [69-71].

\section{Materials and methods}

\subsection{Acquisition and preparation of remote sensing data}

Two types of satellite data were used in this study: (1) multispectral/optical and (2) digital elevation models (DEM). Each image was projected using the WGS-84 Universal Transverse Mercator coordinate system (UTM Zone 19N). Two multispectral Landsat 8 OLI/TIRS (L8) scenes covering the entire study area (Path/raw: 7-52 \& 8-52), were downloaded for free from the digital portal Earth Explorer courtesy of the United States geological service (USGS), and used for classification of geological units. The Landsat 8 OLI/TIRS satellite acquires 11 spectral bands including optical and near-infrared (OLI: "Operational Land Imager") as well as thermal images (TIRS: "Thermal Infrared Sensor"). Spatial resolution varies with wavelength: (1) 30m for bands 1-7 and 9, (2) $15 \mathrm{~m}$ for band 8 (panchromatic) and (3) 100m for thermal bands 10 and 11. Landsat- 8 scenes were preprocessed with the ENVI 5.3 software, to correct the radiometric and atmospheric errors using the FLAASH toolbox.

Three types of DEM with different resolutions were used in order to observe the digital lineament patterns at different scales. These include four Shuttle Radar Topographic Mission (SRTM) images (created using C-band synthetic aperture radar interferometry) with a 90m resolution [82,83]. The SRTM x 90m files were acquired from the USGS website. The second DEM used was the ASTER gDEM, which was derived from the joint project by the Japanese Minister of Economy, Trade and Industry (METI) and the National Aeronautics and Space Administration of the United States (NASA) in 2009. These images are in a GeoTIFF format with geographic 
coordinates, with a resolution of 1 arcsecond (30m). Finally, a DEM with a $12.5 \mathrm{~m}$ resolution was used, which is one of the products of the ALOS mission carried out by the Japan Aerospace Exploration Agency (JAXA) from 2006 to 2011. PALSAR was one of the three instruments on the satellite ALOS which provided L-band synthetic aperture radar DEM files from ALOS mission were downloaded from the NASA website. Table 1 the specification of the downloaded satellite images.

Preprocessing of DEM images is a required step to avoid artificial spikes and isolated pixels that will affect the generated surface $[84,85]$. These anomalies represent local artifacts, arising from different factors such as feature matching techniques, coarse spatial resolution or human activity. For this reason, it is important to consider how much the selected zone is affected by those conditions, in order to improve the image processing and interpretation. The study area presents few recent anthropic structures; in fact, most of the area is Uninhabited because of the arid conditions. An algorithm called Fill was applied to each DEM source using ArcGis 10.5, removing the imperfections.

The Colombian geological service (SGC) through its virtual portal (https://srvags.sgc.gov.co/arcgis/rest/services) provides freely available geological maps of the whole country, digitized in mxd format readable in ArcMap. The map of the Upper Guajira used in this study was created by Rodríguez and Londoño (2002) [70] at a 1:250000 scale. From this map, the lithological, structural and hydrological information was extracted in order to be compared with the results obtained from the automatic delineation of lineaments and drainage network.

\begin{tabular}{|c|c|c|c|}
\hline $\begin{array}{c}\text { Remote Image } \\
\text { Product }\end{array}$ & Spatial Resolution & Scenes & $\begin{array}{c}\text { Download } \\
\text { Source }\end{array}$ \\
\hline $\begin{array}{c}\text { ALOS-PALSAR } \\
\text { DEM }\end{array}$ & $12.5 \mathrm{~m} \mathrm{x} 12.5 \mathrm{~m}$ & $\begin{array}{l}\text { AP_26987_FBS_F0220_RT1 } \\
\text { AP_27235_FBS_F0220_RT1 } \\
\text { AP_26812_FBS_F0230_RT1 } \\
\text { AP_26987_FBS_F0230_RT1 } \\
\text { AP_27235_FBS_F0230_RT1 } \\
\text { AP_27585_PLR_F0230_RT1 } \\
\text { AP_27585_PLR_F0240_RT1 }\end{array}$ & https://vertex.daac.asf.alaska.edu \\
\hline ASTER gDEM & $30 \mathrm{~m} \times 30 \mathrm{~m}$ & $\begin{array}{l}\text { ASTGTM2_N11W072 } \\
\text { ASTGTM2_N11W073 } \\
\text { ASTGTM2_N12W072 } \\
\text { ASTGTM2_N12W073 }\end{array}$ & http://earthexplorer.usgs.gov/ \\
\hline SRTM DEM & $90 \mathrm{~m} \mathrm{x} 90 \mathrm{~m}$ & $\begin{array}{l}\text { n11_w073_1arc_v3 } \\
\text { n11_w072_1arc_v3 } \\
\text { n12_w073_1arc_v3 } \\
\text { n12_w072_1arc_v3 }\end{array}$ & http://earthexplorer.usgs.gov/ \\
\hline Landsat 8 & $\begin{array}{c}30 \mathrm{~m} \times 30 \mathrm{~m} \\
15 \mathrm{~m} \times 15 \mathrm{~m} \\
\text { (Panchromatic) }\end{array}$ & $\begin{array}{l}\text { LC08_L1TP_007052_20160726_20180130_01_T1 } \\
\text { LC08_L1TP_008052_20180301_20180301_01_RT }\end{array}$ & http://earthexplorer.usgs.gov/ \\
\hline
\end{tabular}

Table 1. Information on remote sensing data used in the study.

\subsection{Geological Lineaments}

\subsubsection{Digital processing for delineation and identification of linear features}

In order to identify geological lineaments, linear features from the DEM and Landsat-8 images were extracted. Hillshade techniques are widely used in tectonically active regions in order to delineate linear features with preferential trends [24,29,31,45,47,50,86-89]. Hillshade images simulate a lighting effect from a base point with specific solar altitude and azimuth values, and the linear features showing the maximum enhancement and contrast are those that are perpendicular to the direction of the light source [50].

To extract lineaments with different orientations, eight hillshaded raster images were created for each DEM using the hillshade tool in ArcGIS 10.5 (Fig.2). The first shaded relief image was illuminated from the north (i.e. the solar azimuth was $0^{\circ}$ ), with a solar elevation of $45^{\circ}$ (ArcGIS default); for the other seven relief images, an identical solar elevation was used along with seven other illumination directions, including: $45^{\circ}, 90^{\circ}, 135^{\circ}$, $180^{\circ}, 225^{\circ}, 270^{\circ}$ and $315^{\circ}$. Azimuth illumination and tilt values tend to hide or highlight morphological features in a hillshaded image, depending on their orientation with respect to the simulated light source. The next step consisted of applying the MDOW (multi-directional oblique weighted) shaded relief method [29,91], in which two multi-illumination hillshaded images were created from combinations of the individual shaded relief images. These combination images highlight lineaments and topographic features with a variety of directions, which would not be visible if only a single shaded image was used. The first four shaded relief images were superimposed and combined to produce one image with multi-illumination directions $\left(0^{\circ}, 45^{\circ}, 90^{\circ}, 135^{\circ}\right.$ - 

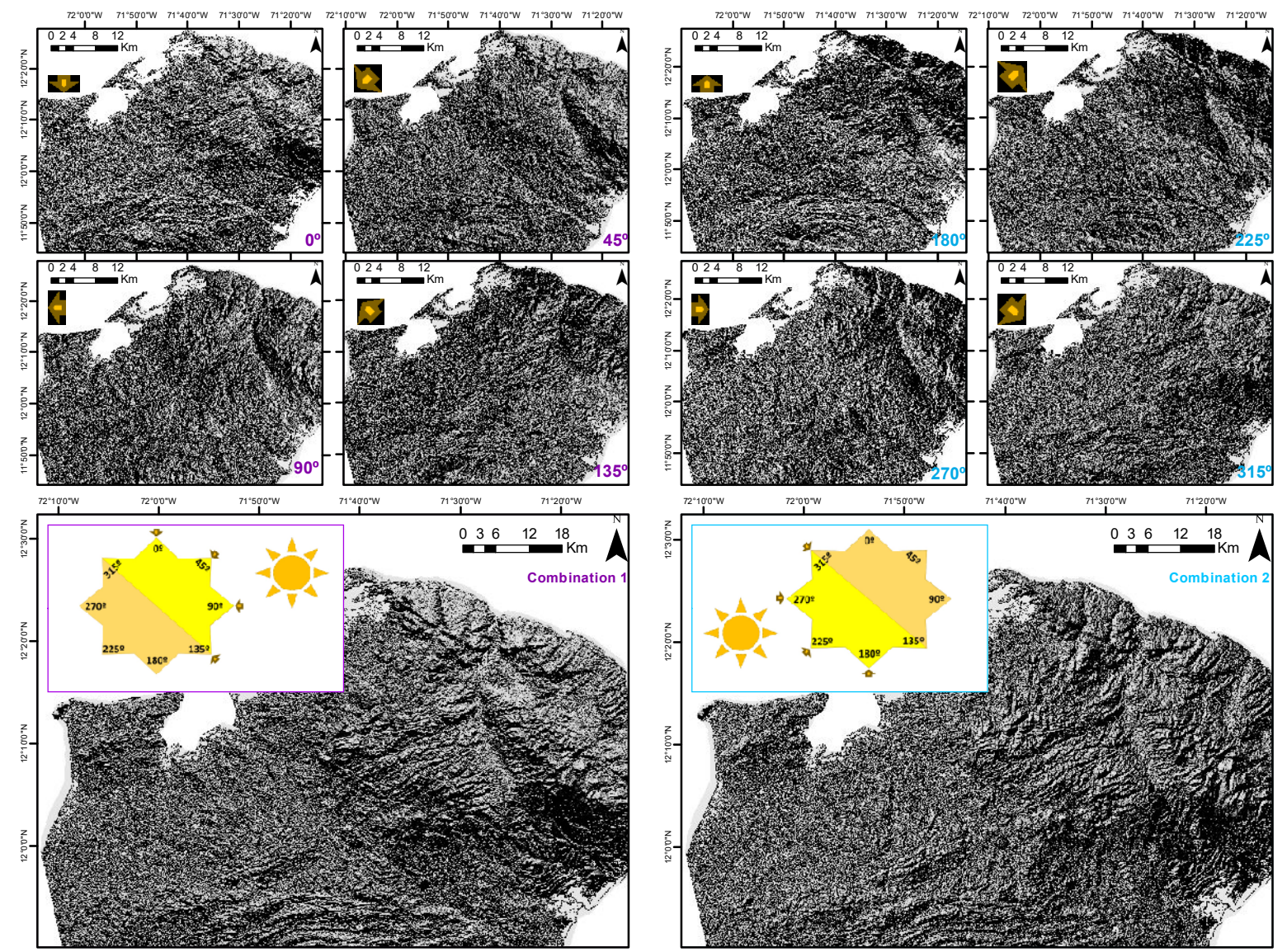

Figure 2. Example of eight hillshaded raster images with a constant light dip of $45^{\circ}$ and various light azimuths $\left(0^{\circ}, 45^{\circ}\right.$, $90^{\circ}, 135^{\circ}, 180^{\circ}, 225^{\circ}, 270^{\circ} \& 315^{\circ}$ ), covering part of the study area, derived from the SRMTx $90 \mathrm{~m}$ DEM. The same process were done for the Alos Palsar DEM and ASTER DEM. Two Multi-illumination hill-shaded images resulted from combining hillshaded images: combination 1 includes hillshaded images from $0^{\circ}-135^{\circ}$ light dip and combination 2 includes the rest of the hillshaded images (i.e. from $180^{\circ}-315^{\circ}$ ).

Combination 1), and the four remaining images $\left(180^{\circ}, 225^{\circ}, 270^{\circ}\right.$ and $315^{\circ}$ - Combination 2) were processed in the same way (Fig.2). For a comparative and complementary analysis in the detection of geological lineaments, bands 7 and 8 of the Landsat- 8 data were used. Band 7 has been useful for lithological discrimination and the extraction of morphotectonic features such as lineaments [29,47,48,93]. The panchromatic band (band 8 ) has a resolution of $15 \mathrm{~m}$ allowing the extraction of a greater quantity of useful information, mapping of lineaments, and detection of physical characteristics of the terrain in greater detail.

The Multi-illumination hillshaded images and the bands 7 and 8 of Landsat- 8 were uploaded to the PCI Geomatica 2012 software [92] and a LINE algorithm was applied in each dataset in order to extract linear features (i.e. lineaments). LINE module requires three stages: (1) detection of edges, (2) thresholding of the image and (3) extraction of curves. The result for each dataset is a vector layer of polylines. The operation of the algorithm requires a group of parameters for its execution: RADI (Filter Radius) $=24$; GTHR (Edge Gradient Threshold) $=70$; LTHR $($ Curve Length Threshold) $=30$; FTHR $($ Line Fitting Threshold $)=7$; ATHR (Angular Difference Threshold $)=7$; and DTHR (Linking Distance Threshold) $=70$. The choice and understanding of each parameter were based on previous works [24,29,50] and the software manual. Each vector layer was upload in ArcGIS 10.5 in order to be processed and analyzed. Some lineaments were paired with anthropogenic structures (i.e. roads, buildings, etc.), coastal limits and/or possible errors related to the cloudiness in the images (i.e. ASTER gDEM and Landsat 8), so after a visual review, the lineaments corresponding to the mentioned pairings were deleted manually (Table.2). 


\subsubsection{Methodology used for the analysis of digital lineaments}

The numerical values of lengths and directions were obtained for each set of lineaments using the ArcMap 10.5 COGO tool. For each group of lineaments rose diagrams were created to determine the dominant azimuth direction and its physiographic subdivisions. Determining the dominant direction based on the lineament frequency can include some errors given that the lineaments drawn automatically are usually short in length, and many individual samples could represent a long and unique line [29], so the rose diagrams allow the identification of the lineament lengths. Rose diagrams were done using dynamic tables tool in Microsoft Excel 2016 software. The parameters of the rose diagrams carried out in this research are [24,88,89]:

A) The number of lineaments $(\mathrm{N})$ determined the number of lines over a specific area.

B) The total length of lineaments defined the sum of lengths of all lineaments in the study area.

C) The morphotectonic network density $\mathrm{D}$ is defined by the following equation: [Density $=N / A$ ]], where A is the area of a particular region.

D) The azimuth trend of lineaments determined the lineament orientation respect to a specific geographic coordinate system. The azimuth of lineaments is illustrated by rose diagrams, which are divided into 72 intervals of $5 \circ$ (i.e. In total 360。) moving clockwise.

Different types of density maps of each lineament sample and their merging derivatives were created in order to understand their spatial distribution, the highlight faults, weakness zones and high topographic changes [30,44,51,94]. Furthermore, lineament samples were ordered and distributed with respect to the age of the geological units according to the SGC geological map (1C), thus evaluating the azimuth trend along the geological timeline [29].

Using the fault polylines of the SGC map, we created a Riedel Shear model which allowed us to understand the historical activity of faults due to strike-slip motion, such as the CF. This kind of model can only be applied in zones where strike-slip faults occur, so transtensional and transpressional regimes, such as the ones that have occurred along the boundary between the Caribbean and South American plates, are good areas to use this kind of model. Thus, some lineaments can be related to deformational elements (i.e. R and R' fractures) formed by the strike-slip motion due to the regional kinematics based in in the Riedel model classification, by assuming that regional linear features can be classified with this method within a zone that presents a transpressional tectonic arrangement.

\subsection{Lithological discrimination from Landsat-8 multispectral data}

In addition to the linear analysis of faults and lineaments, Landsat 8 images were used to show typical morphological features of the tectonic regime that have evolved over the area. For this research Landsat- 8 multispectral images integrated with GIS techniques applied using ArcGIS 10.5, PCI Geomatica 2012 and ENVI 5.3 to map and discriminate the lithology and structural features of selected zones of the Upper Guajira. Multispectral images consists of the three visual primary color bands (red, green, blue) in addition to the longer-wavelength bands. These three bands (432) may be combined to produce a TCC (True Color image), which is one of the techniques used to select bands for a visual interpretation. The Principal Component Analysis (PCA) transformation is a multivariate statistical technique that selects uncorrelated linear combinations (eigenvector loadings) of variables, in such a way that each component successively extract linear combinations of all the digital numbers of the other band images and has a smaller variance. PCA were computed for the Landsat- 8 data to discriminate physical features and lithological units in the study area. These PCA images were assigned to the display colors (Red, Green and Blue) respectively to form PC-color composite image in order to differentiate between the different rocks assemblage of the area as these are the three components that best reflect lithological variations [48]. The PC-5, PC-3 and PC-2 composite proved to be significant to discriminate between geological features. 


\subsection{Delineation of drainage networks}

In tectonically active regions, drainage networks are often strongly influenced by the orientation of geological structures [29,32,88], reflecting the interaction between surface processes with the faults and folds that have been formed over a tectonically active area [96-99]. Drainage networks may indicate local deviations from the predominant patterns, which help identify neotectonic activity in different tectonic settings [29]; thus, the automatic identification of drainage networks and drainage basins from DEMs has become an important tool to include in a morphotectonic analysis [100].

Modern GIS software packages make it possible to extract an automatic drainage network and drainage basins from a DEM [26,28-30,101]. In this work, the SRTM DEM was selected for the extraction of drainage network and basins, because its relatively low spatial resolution $(90 \mathrm{~m})$ allows for rapid processing [30]. This automated delineation of the drainage network was done by using the GIS Flow accumulation method [42] based on the hydrological manual made by ESRI (2011)[102]. The tool Hydrology of ArcMap 10.5 was used for the stream network delineation. The extraction of drainage patterns is a multi-step process and includes: (1) Sink filling (Pre-processing), (2) flow direction identification, (3) flow accumulation calculation, (4) stream definition and segmentation, and (5) Strahler Stream order classification. The threshold raster defines the cell values that are determined to have enough accumulation to be classified as a stream, and the threshold raster is generated from a raster created by the Flow Accumulation tool. Flow accumulation raster is in simplest form the number of upslope cells that flow into each cell. By applying a threshold value to the results of the Flow Accumulation, a stream network can be delineated. Low value thresholds lead to an increase in the level of detail of the stream networks [29], so for this research the value was 500, value that provides to be workable for drainage network deliniation.

The network streams were split into several segments based on their orientations using the "Split Line at Vertices" tool in order to segment the vector stream polylines, thus avoiding errors in the analysis due to the sinuosity and topography of the area. The COGO toolbar of ArcMap was also used to extract the orientation and length for each drainage channel segment.

Knickpoints (sometimes referred to as knick zones), are discontinuities or steep segments in a river profile which are usually a response to stream power, climate changes, lithological instability, or tectonic deformities $[100,103,104]$. In this study we also attempt to identify knickpoints on longitudinal stream profiles in order to assess whether they have lithological and/or tectonical disturbances [107,108,140].

\section{Analysis and results}

\subsection{Morphometric analysis of lineaments}

Here we evaluate the automatically extracted lineaments in order to analyze their tectonic implications. Lineament density maps of frequency, intersection and length are used in order to visualize and characterize the spatial patterns of the lineaments [44,109].

\subsubsection{Length Analysis}

Morphometric results from the three DEM images are shown in Figure 3, in which it can be seen that the Alos Palsar scenes detect more than twice the number of lineaments detected by the other two DEM images, with lengths mainly between $0-1 \mathrm{~km}$. The length of the polylines from ASTER and SRTM images are similar, but SRTM lineaments show a greater number of samples due the cloud errors over the Macuira zone in the ASTER image. Lineaments from Landsat 8 have the shortest lengths, but band 8 samples are greater in number due to the higher resolution of band 8 compared to the other bands. Table 2 summarizes the results of the lineament samples detected from the satellite images and the lenght of the lines that represent the faults of the Upper Guajira, according to the SGC digital geological map. 

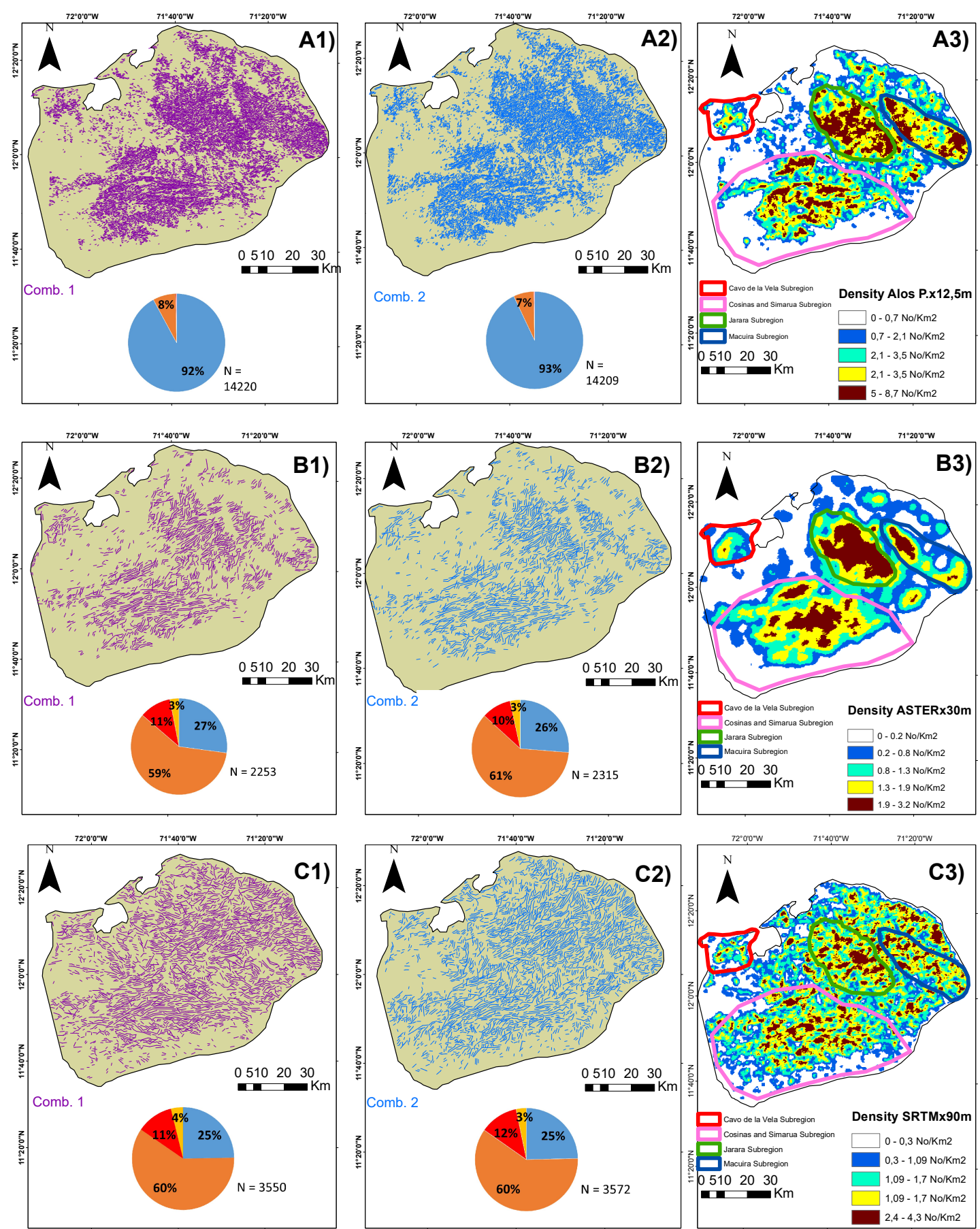

\begin{tabular}{llll}
\hline$-0-1 \mathrm{Km}$ & $-1-2 \mathrm{Km}$ & $-2-3 \mathrm{Km}$ & $->3 \mathrm{Km}$ \\
\hline
\end{tabular}

Figure 3. Distributions and densities of lineaments obtained from different DEM images. A:Alos Palsar; B:ASTER gDEM; C: SRTM. 1: Combination 1; 2: Combination2 ; 3: general Frequency Density map of both DEM lineament combinations. All density maps were created using a radius of $1 \mathrm{~km}$. The zones of maximum density anomalies probably indicate a higher intensity of deformation. The legend below the maps indicates the lengths of the digital lineaments, and that the percentage in the pie diagrams indicate the percentage the lineaments for each combination)

\subsubsection{Lineament Frequency Density Analysis}

The purpose of the lineament frequency density analysis is to calculate the distribution of number of lineaments per unit area [43]. This analysis is also known as lineament frequency analysis [94]. We produced 


\begin{tabular}{|c|c|c|c|c|c|c|c|}
\hline \multicolumn{2}{|c|}{ Character } & \multirow{2}{*}{$\begin{array}{c}\text { Original } \\
\text { No. Lineaments } \\
\text { (Without Revision) } \\
15159\end{array}$} & \multirow{2}{*}{$\begin{array}{c}\begin{array}{c}\text { No. } \\
\text { Lineaments }\end{array} \\
14220\end{array}$} & \multirow{2}{*}{$\begin{array}{c}\text { Min. } \\
\text { Length }(\mathrm{Km}) \\
0.024\end{array}$} & \multirow{2}{*}{$\begin{array}{c}\text { Max. } \\
\text { Length }(\mathrm{Km}) \\
2.97\end{array}$} & \multirow{2}{*}{$\begin{array}{c}\begin{array}{c}\text { Average } \\
\text { Length }(\mathrm{Km})\end{array} \\
0.47\end{array}$} & \multirow{2}{*}{$\begin{array}{c}\begin{array}{c}\text { Total } \\
\text { Length }(\mathrm{Km})\end{array} \\
8428.08\end{array}$} \\
\hline Alos-Palsar & Comb. 1 & & & & & & \\
\hline DEM & Comb. 2 & 15140 & 14209 & 0.024 & 3.59 & 0.45 & 8210.98 \\
\hline \multirow{2}{*}{$\begin{array}{c}\text { ASTER } \\
\text { gDEM }\end{array}$} & Comb. 1 & 2541 & 2253 & 0.06 & 8.76 & 1.09 & 3146.21 \\
\hline & Comb. 2 & 2607 & 2315 & 0.06 & 5.87 & 1.09 & 3210.79 \\
\hline \multirow{2}{*}{$\begin{array}{c}\text { SRTM } \\
\text { DEM }\end{array}$} & Comb. 1 & 3871 & 3550 & 0.06 & 9.63 & 1.14 & 5084.50 \\
\hline & Comb. 2 & 3903 & 3550 & 0.06 & 9.63 & 1.13 & 5084.65 \\
\hline \multirow{2}{*}{ Landsat 8} & Band 7 & 3171 & 1760 & 0.0021 & 9.23 & 1.03 & 2572.16 \\
\hline & Band 8 & 8212 & 7031 & 0.0004 & 4.48 & 0.61 & 5278.26 \\
\hline \multicolumn{2}{|c|}{ SGC Faults } & - & 4390 & 0.006 & 7.59 & 0.167 & 1368.64 \\
\hline
\end{tabular}

Table 2. Statistical summary of the automatic lineament maps, with the number and length of the extracted lineament samples from different satellite images used.

several maps showing the concentrations of the different extracted lineament groups over the area (Fig.3). This map was created using ArcGIS 10.5 by counting the number of lines per unit area (No. Lineaments $/ \mathrm{km}^{2}$ ). A general frequency density map of all the lineament groups was produced (Fig.4A)

Lineaments were subdivided into different classes such as Low $\left(<1.3\right.$ No. Lin $\left./ \mathrm{km}^{2}\right)$, moderate $(1.3-3.7$ No. $\left.\operatorname{Lin} / \mathrm{km}^{2}\right)$, high $\left(3.7-6.3 \mathrm{No}\right.$. Lin $\left./ \mathrm{km}^{2}\right)$, very high $\left(6.3-8.9 \mathrm{No}\right.$. Lin $\left./ \mathrm{km}^{2}\right)$ and maximum $\left(>8.9\right.$ No. Lin $\left./ \mathrm{km}^{2}\right)$. In in a large part of the study area of the study area (37\%), the density of lineaments at a maximum, corresponding to the zones with notable topographical changes (i.e. physiographic divisions of the area), while the areas with low (9\%) and moderate (17\%) densities correspond to flatter areas. Areas with high and very high densities comprise $19 \%$ and $18 \%$ of the region respectively. Studies have shown that areas with a high density of lineaments tend to have a high intensity of deformation [110], high degree of rock fracturing [111], shearing [112], permeability [113], higher ground water yield [114], mineral occurrences associated with hydrothermal alteration zones [115], higher soil erodibility [116], slope failures [115], steeper slopes [31] and/or regional faults [29].

\subsubsection{Lineament Length Density Analysis}

A lineament length density map is a useful guide to understanding the zonation of the lineament samples (Fig.4B1) [44,117]. This analysis is also known as lineament-length density [94] and consists of calculating the lengths of the lines completely contained within a cell limit $[31,43,118]$. Thus, the total length per unit area is calculated using all the lengths of the lineaments that are completely contained within a specific cell, and is expressed in $\mathrm{km} / \mathrm{km}^{2}$ [44]. For each group of lineaments from each DEM image, a lineament length density map was produced, so the length density maps were extracted by merging the two lineament combinations of each DEM due to the similar lengths observed for both combinations in the lineaments extracted from each DEM (Tab. 2). A general length density map was created by merging all the lineament combinations from all DEM samples (Fig.4B1). The most distinguished feature observed in the four maps is the high concentration along the $\mathrm{CF}$, which is geometrically enhanced on the maps, meaning that the longest fractures segments in the area are observed along the $\mathrm{CF}$.

Morphometrically, the lineament-length density maps show some variations depending on the type of image used: (1) The density measures were lowest for the Alos Palsar DEM, which is the one that presents the biggest population of lineaments(Fig.4B2). (2) In the ASTER gDEM, over the Macuira serrania there is a blank zone due to the clouds, which is reflected in the density measures (Fig.4B3). (3) For the SRTM length density map (Fig.4B4) it can be seen that lengths of the lineaments vary more throughout the area. Other concentrations observed in the area are: (1) the highest concentrations over the Jarara serrania, with lineaments preferentially elongated along the NW-SE direction; (2) all the physiographic divisions are highlighted and (3) Macuira serrania does not have the same density concentrations as Jarara serrania, but its geometric position is elongated in the same direction.

\subsubsection{Intersection Density Analysis of lineaments}

Lineament intersection density maps (Fig.5) show the intersection frequencies of each lineament combination samples in a unit cell (No. Intersections $/ \mathrm{km}^{2}$ ). Two maps were generated for each combination of 

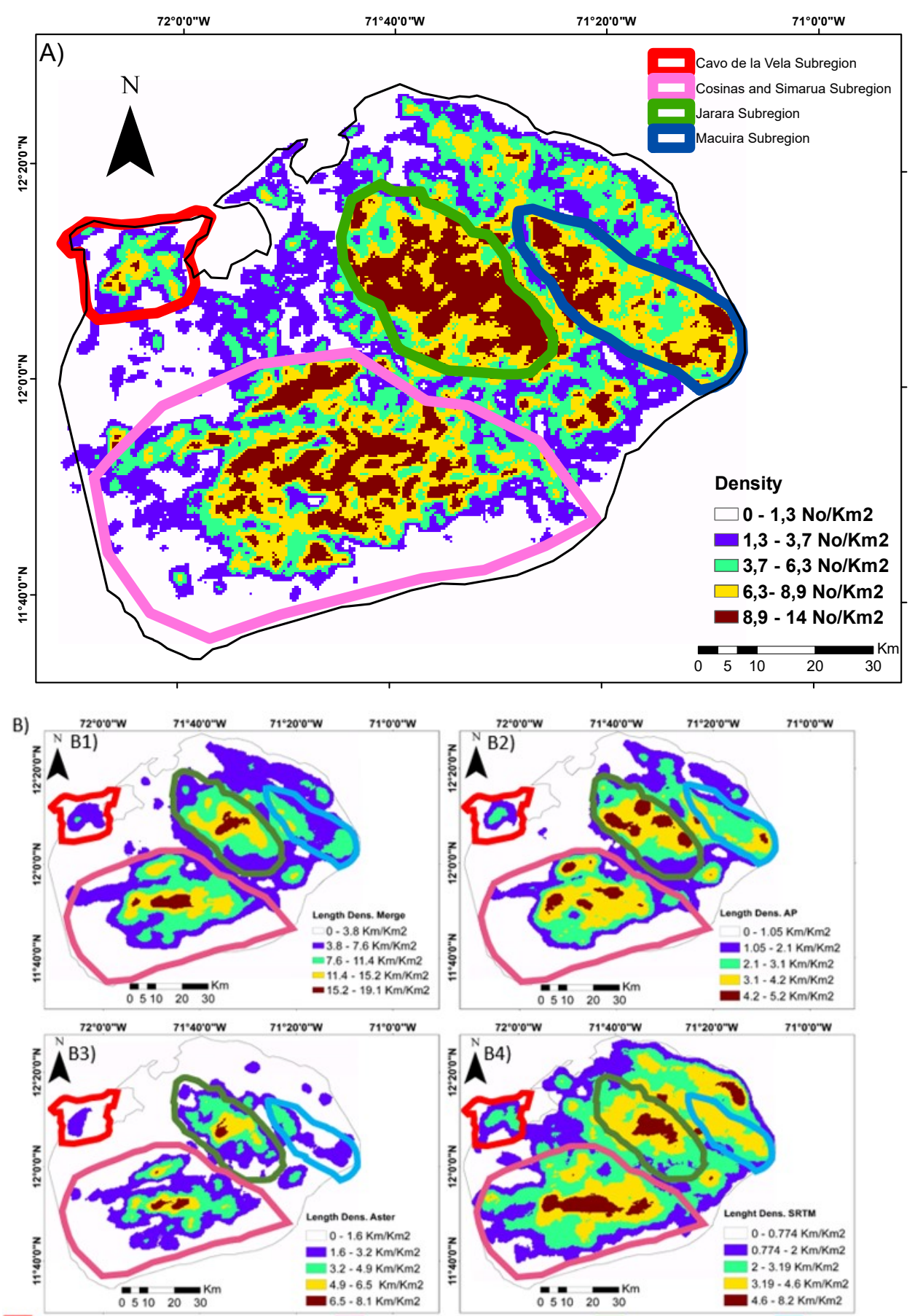

Cavo De la Vela and Carpintero subregion $\quad \square$ cosinas and Simarua subregion $\quad \square$ Jarara subregion $\quad \square$ Macuira subregion

Figure 4. Lineament density maps of the Upper Guajira area. A) General lineament frequency density map of all samples. Flat zones suggest fewer lineaments due to the thick covering of sands limiting the visibility at the surface. B) Length densities of lineaments extracted from DEM images. 1= Merged lineaments from all samples; 2=Alos Palsar; $3=$ ASTER gDEM; 4=SRTM. For this analysis combination 1 and 2 lineament samples were combined for individual DEM data source. Longer lengths of lineaments indicate faults in the physiographic areas. CF is strongly highlighted with this method.

lineaments extracted from each DEM, as well as two general intersection density maps were generated from the union of the all lineament lineament intersections of combinations 1 and 2 respectively. Based on a visual comparison between all density maps, a high correlation was found between areas with high density levels. The purpose of using intersection density maps is to identify areas of greatest fracture [44,119]. When the lineament segments do not intersect in the cell, the resultant map will be planar, with almost no density contours. The zones of high lineament intersection over the study area are feasible zones for the evaluation of fractures or the 

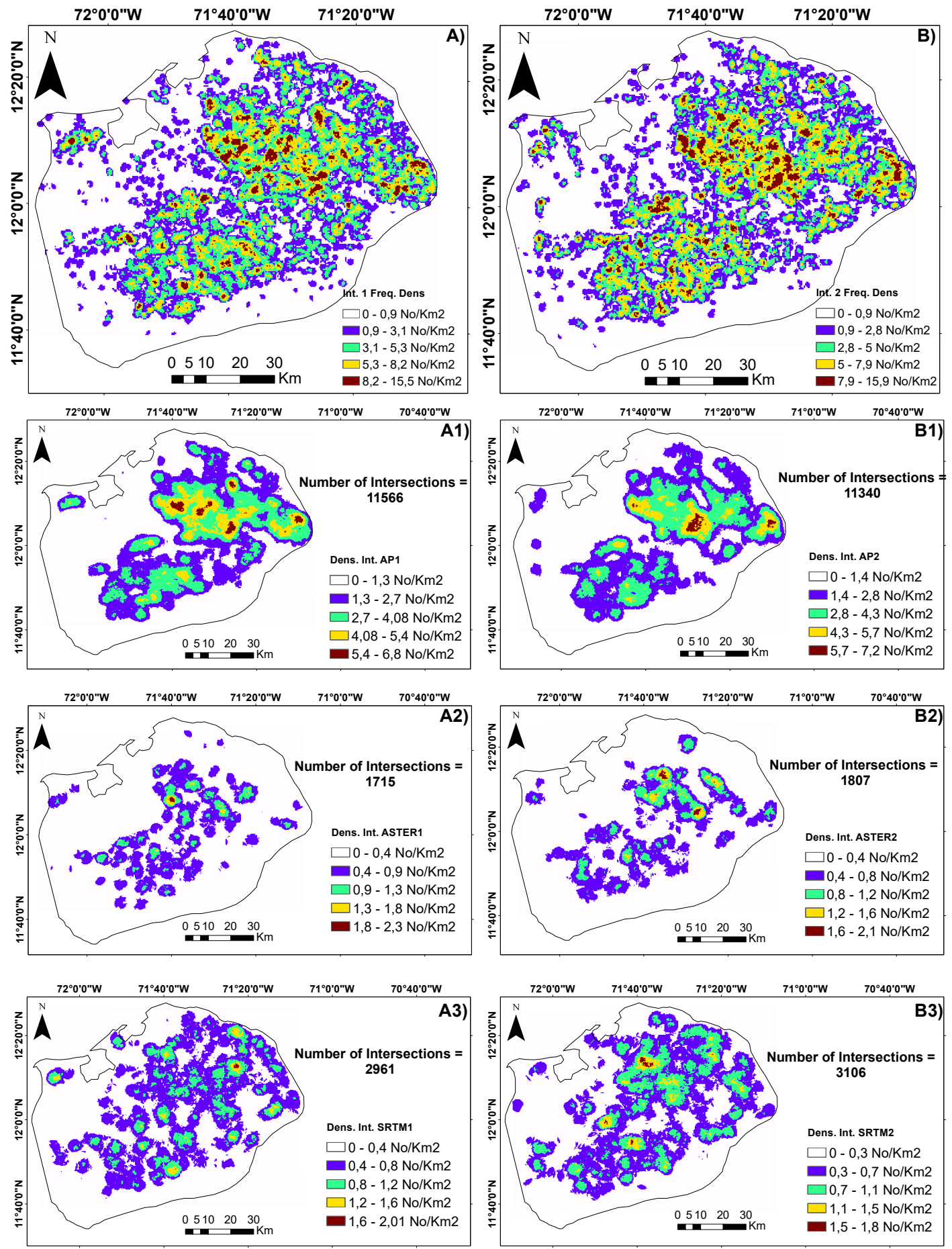

Figure 5. Lineament intersection density maps of the Upper Guajira region. Six maps were generated for each combination of intersection lineaments extracted from each DEM raster, as well as two general intersection density maps from the union of all lineament intersections of combinations 1 and 2 respectively. A) intersection lineaments derived from Combination 1 of each DEM . B) Intersection lineaments derived from Combination 2 of each DEM dataset, 1: Alos Palsar, 2: ASTER gDEM, 3 : SRTM. High intersection zones delimit highly fracture areas.

evaluation of potential water reservoirs because the areas with the greatest intersection lineaments tend to be areas in where water has a greater possibility of flowing [44].

The Alos Palsar DEM shows a greater quantity of intersections, enhancing more specifically the zones with 
highest densities compared to other DEMs intersections. ASTER gDEM lineament intersections show a lower quantity of intersections, but the density spatial distribution is more zonated than the SRTM patterns. The intersection density measures of the SRTM and ASTER individuals are very similar, unlike the Alos Palsar density measure which shows higher measure values due the quantity of the specimens. Combining the individuals of the combination 1 and 2 individually allowed us to refine more zones with high concentrations of intersections.

\subsection{Comparison of extracted lineaments and faults, an orientation analysis of the structural features}
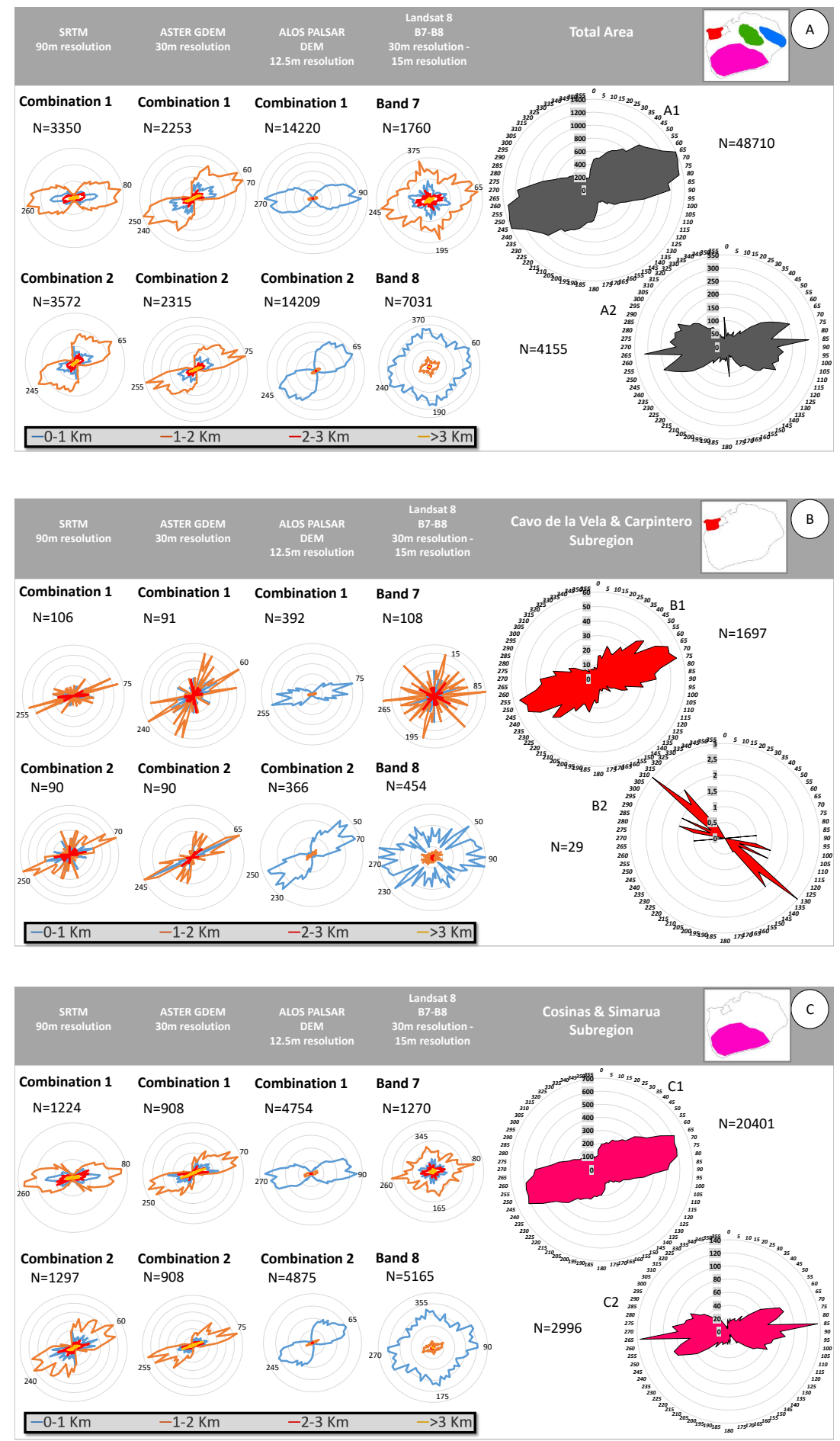

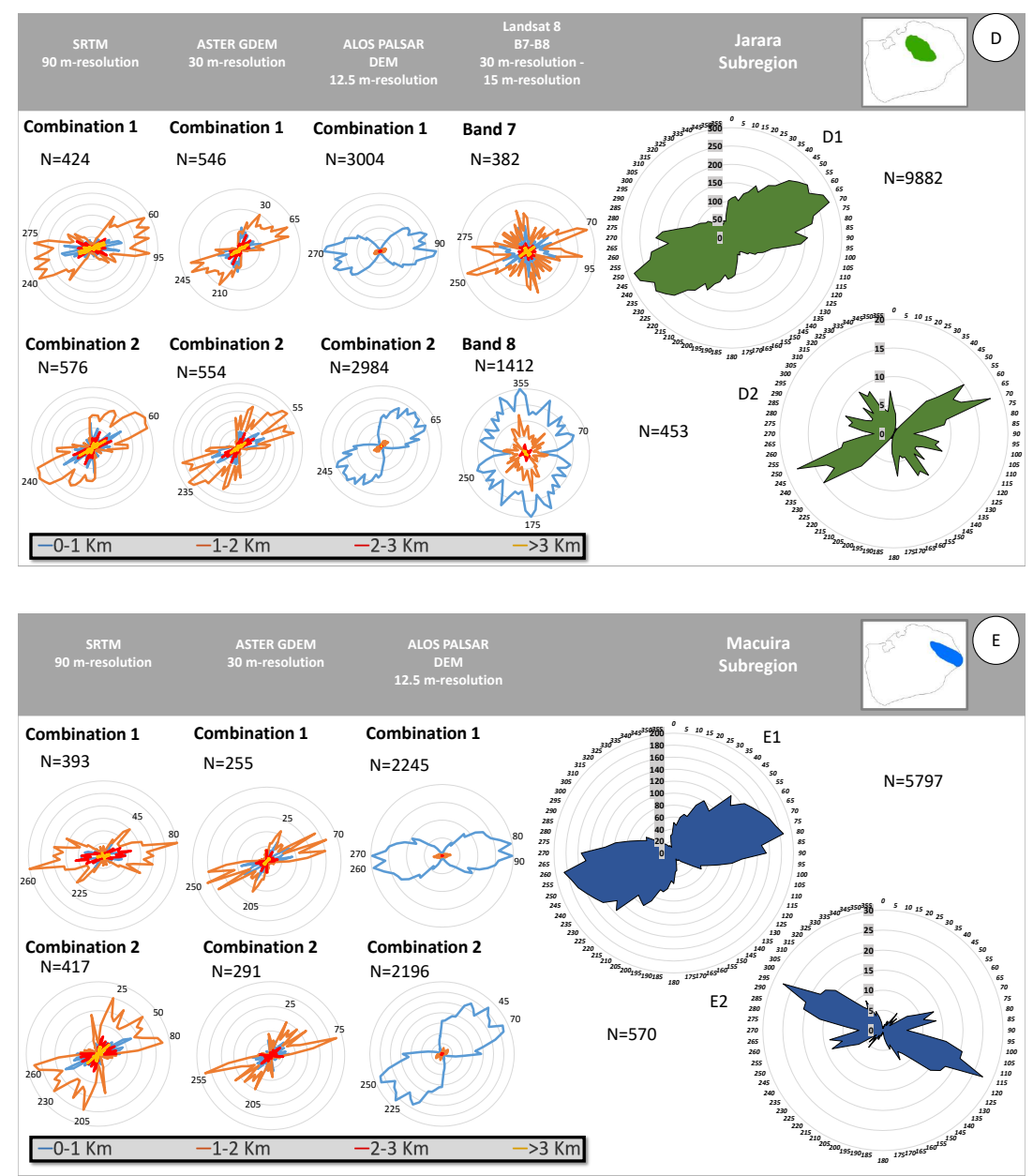

Figure 6. Azimuth of extracted SGC faults and lineaments delimited by physiographic subregions. A) Total area, B) Cavo de la Vela and Carpintero subregion, C) Cosinas and Simarua Subregion, D) Jarara Subregion, E) Macuira Subregion. 1: Rose Diagram of merge lineaments for each area, 2:Rose Diagram of faults for each area.

Orientation is one of the most revealing characteristics of linear features over the surface. Thus, linear features along the study area were interpreted using rose diagrams, whereby length and frequency of these linear features are also represented according to the azimuths tendencies. A detailed analysis of azimuth distributions of extracted lineaments and faults was performed for the whole area (Fig.6A) and individual subregions were delimited by physiographic regions.

The Upper Guajira was divided into four physiographic units (Table 3), in order to compare them with the diagrams of the faults and lineaments. The units are as follows from west to east:

a) Cabo de la Vela and Carpintero subregion (Fig.6B): Located at the northwestern zone of the Upper Guajira. This region presents the most unequal azimuth directions between the lineaments (NE-SW) and the reported faults (NW-SE). The low number of faults in the zone allows a visual descriptive analysis of this area, so our hypotheses for dissimilar azimuth directions are: (1) Faults are not very abundant and are only detected in metasediments and metaconglomerates rocks from late Cretaceous; with similar ages as the ones observed in Cabo de la Vela ultra-mafic complex (i.e. Ophiolite zone) from late Cretaceous (Campanian), in contact with poorly consolidated tertiary deposits of gravel and sand, so those faults could be controlled due the ophiolite accretion $[57,120,121]$. (2) The dextral movement of the Caribbean plate between Late Cretaceous-Paleogene may be related to the lineament azimuths in the zone, so the position of the faults could be associated to the rotation that the Guajira peninsula and SNSM underwent during these periods $[3,76]$. The faults over these zones could be geometrically positioned due to this rotation, so their original azimuth could be NE-SW but rotated 
almost $90^{\circ}$ to a NW-SE position. (3) Lineaments in this subregion are not directly related to faults, being evident in the different linear orientations as they are probably related to the convergence of the Caribbean plate rather than by the motion of these faults, which do not seem to be identified through the analysis of lineaments. So lineaments do not highlight the faults reported by the SGC map. A visual interpretation of the lineament maps shows that the DEM with higher resolution better delineates the lineaments over this region.

b) Cosinas and Simarua subregion (Fig.6C): Is the largest zone of all, merging the Cosinas and Simarua serranias where the CF deformation is more evident. Lineaments and faults show a strong relationship between their azimuth trendings. The biggest peak in the fault rose diagram of the faults corresponds to the CF system, the second one corresponds to the Cosinas and Simarua thrust faults system.

c) Jarara subregion (Fig.6D): This zone also reflects a good relationship between the azimuth trending of faults and lineaments. The only difference between them lies in the particular distribution faults in the NW-SE direction, whose origin will be explained in next sections.

d) Macuira subregion (Fig.6E): In this zone the NE-SW azimuth trends have predominance in faults and lineaments, but in the fault rose diagram a NW-SE trend appears. This differences in trends are a result of the normal faults family, which will be discussed later. Landsat 8 lineaments could not be identified due to the cloudiness over the area.

The preferential direction of all the extracted lineaments in all the physiographic regions and for each digital image is a NE-SW azimuth for the whole area (Fig.6A), equal to the one presented in the fault diagram for the whole area. There are differences between the directions of faults and lineaments in the Cabo de la Vela \& Carpintero and Macuira zones, in which the faults have a preferential azimuthal direction of NW-SE. It is important to note that the extracted lineaments from bands 7 and 8 of the Landsat 8 image show azimuthal directions in various orientations, It should be noted that the major geological contacts have a NE-SW trend similar to one of the major trends of lineaments.

\begin{tabular}{|c|c|c|c|c|c|}
\hline Subregions & $\begin{array}{c}\text { Area } \\
\left(\mathrm{Km}^{2}\right)\end{array}$ & $\begin{array}{c}\text { No. } \\
\text { Lineaments }\end{array}$ & $\begin{array}{c}\text { No. } \\
\text { Faults }\end{array}$ & $\begin{array}{c}\text { Azimuth of } \\
\text { Lineaments }\end{array}$ & $\begin{array}{c}\text { Azimuth of } \\
\text { Faults }\end{array}$ \\
\hline $\begin{array}{c}\text { Complete } \\
\text { Study Area }\end{array}$ & 7640 & 48710 & 4155 & I)NE-SW & $\begin{array}{c}\text { I)E-W } \\
\text { II)NE-SW }\end{array}$ \\
\hline $\begin{array}{c}\text { Cavo de la Vela } \\
\text { \& Carpintero }\end{array}$ & 300 & 1697 & 29 & I)NE-SW & I)NW-SE \\
\hline $\begin{array}{c}\text { Cosinas } \\
\text { \& Simarua }\end{array}$ & 2700 & 20401 & 2996 & I)NE-SW & $\begin{array}{c}\text { I)E-W } \\
\text { II)NE-SW }\end{array}$ \\
\hline Jarara & 743 & 9882 & 453 & I)NE-SW & $\begin{array}{c}\text { I)NE-SW } \\
\text { II)NW-SE }\end{array}$ \\
\hline Macuira & 560 & 5797 & 579 & I)NE-SW & $\begin{array}{c}\text { I)NW-SE } \\
\text { II)NE-SW }\end{array}$ \\
\hline
\end{tabular}

Table 3. Statistics of the trend direction of lineaments in each studied area.

\subsection{Chronological implications of lineaments}

One of the most distinctive characteristics of the Upper Guajira peninsula is the series of isolated crystalline massifs between flat Cenozoic basins [57,122,123]. Geological units with ages ranging from Proterozoic to Neogene are exposed and can provide relative constraints on the lineaments that cross them. The method consists of detecting changes in lineament orientations through geologic periods and correlating these pattern changes with the geological evolution of the Caribbean plate. So the reliability of lineaments ages depends on the precision of the geological map [70]. All lineament samples of all DEM data were merged, and for each geological period units, lineaments were analyzed using the same morphometrical parameters that were used in the previous section. Only the lineaments that were totally within a polygon with an established period (according to the geological map) were used; the lineaments that were found cutting more than one geological unit were not taken into account for this analysis. The classification of all lineaments was performed and six populations were obtained: the ones 
A)

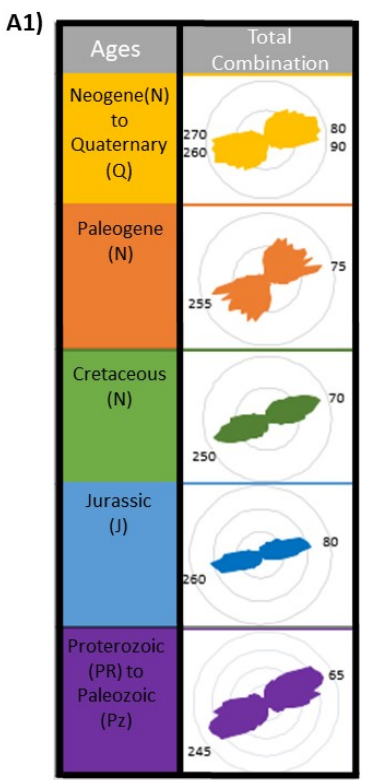

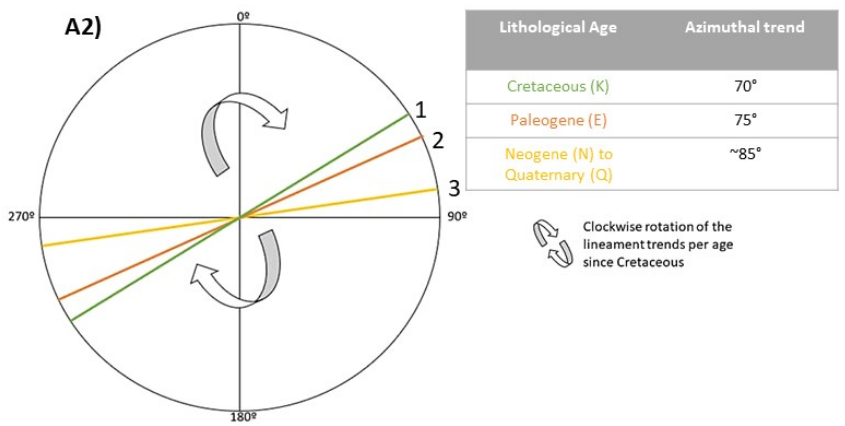

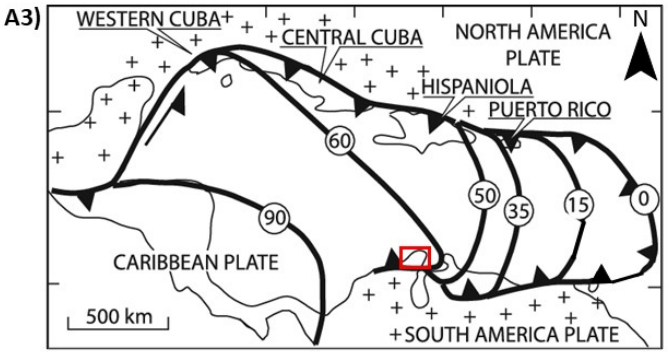

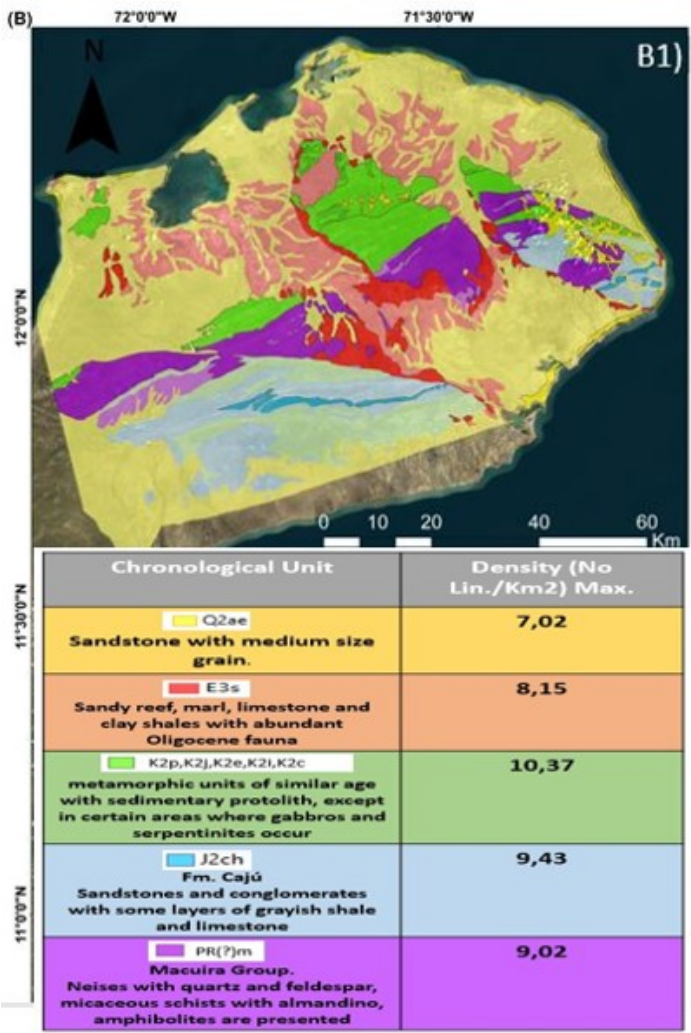

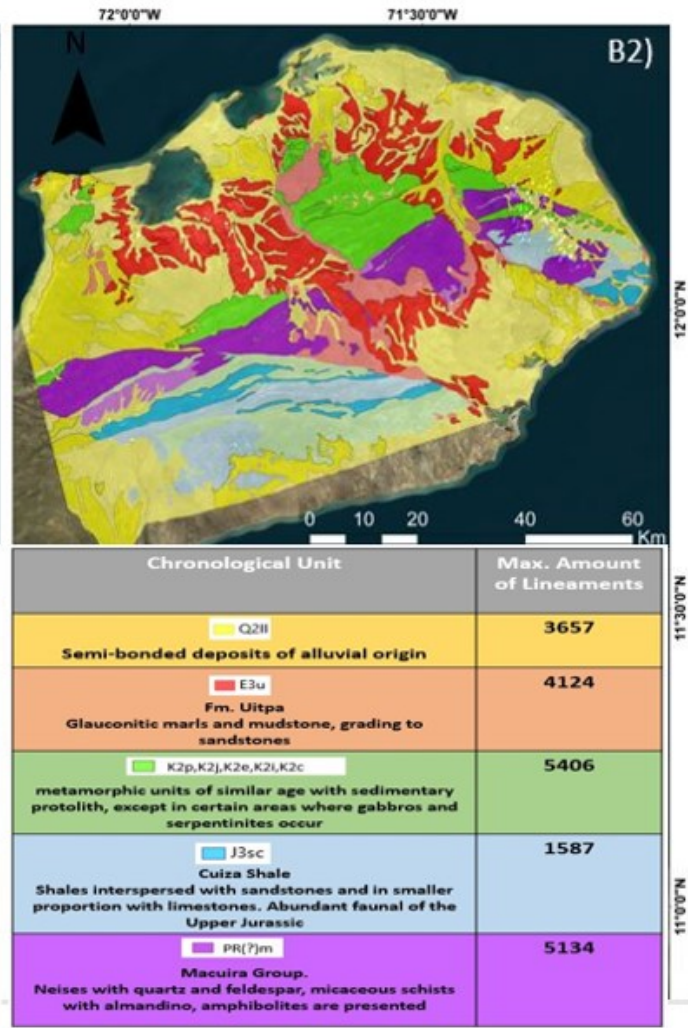

Figure 7. A)Temporal evolution of the lineament trends in the Upper Guajira. A1) Frequency weighted rose diagrams representing the strike directions of extracted lineaments. Lineaments show a clockwise rotation since Cretaceous. A2) Scheme of lineament showing the possible rotation since Cretaceous. A3) Time evolution of the Caribbean plate boundary from 90 to $0 \mathrm{Ma}$ as labeled. Since about $60 \mathrm{Ma}$ the southern edge of the Caribbean plate boundary has been interacting with the northern boundary of the South America plate. Modified from Lugo and Mann,1995 [124] \& Christeson et al., 2008 [125]. B) Behavior of lineaments according the densities and quantity of lineament samples showing which lithological units are most influenced by lineaments, and how they are distributed in the areas with higher values of digital lineament samples per geological periods. Enhanced units correspond to higher results, labelled by chronological order. B1) Map presenting higher densities (No. Linements $/ \mathrm{km}^{2}$ ) over the area due to the geochronological units division. B2) Chronological units with higher quantity of samples per lithological unit, for each chronological period defined for this analysis. 
observed in a Precambrian basement (Proterozoic eon), two Mesozoic families from Jurassic and Cretaceous and three from all Cenozoic periods (i.e. Paleogene, Neogene and Quaternary).

Temporal evolution of the lineament trends in various geologic units is shown in Figure 7A. Its important to take into account that the age of the rock determines only a maximum age of the lineament formation. Real age can be much younger, but younger rocks should be high related to younger lineaments. One important consideration is that the lineaments of the Quaternary and Neogene periods were interpreted in the same population group. The lineament samples show a clockwise rotation of nearly $5^{\circ}$ per period since the Cretaceous (Figs.7A1 \& A2). The evolution of this trend resembles the clockwise ENE rotation of the Caribbean plate [124,125] (Figs.7A3).The quantity of lineaments within each polygon that contain a group of lineament samples, allowing us to produce quantitative distribution per geological periods (Fig.7B). This classification consists of enhancing the rock units that show higher density and greatest number of lineaments [29]. The metamorphic units have the highest population densities of measured lineaments in lithological units and chronological units, however, as is shown in the maps, not all cases in which there is a greater quantity of lineaments will present greater density measures (Fig.7B). It could be observed that in spite of the fact that the sedimentary rocks have a large territorial area and a greater population of lineaments, the population density in this type of rocks is lowest, this could be related because the unconsolidated units present in the Upper Guajira ([3,70]). Cretaceous units present higher densities and larger number of lineaments, suggesting that these units could present significant amount of deformation over the area, this could be also related to the collision of the Caribbean plate with the North and South American plate margins during the uppermost Cretaceous and Tertiary, process that may have been accompanied by a change in polarity of subduction, from eastward-dipping subduction of the Pacific below the Proto-Caribbean to westward-dipping subduction of the Proto-Caribbean below the Pacific (Caribbean) [3,4,61]. So, the highest densities (No. Lin/Km2) of lineaments (Fig.7B1) and the highest amount of lineaments (Fig.7B2) in the Upper Guajira are presented in cretaceous metamorphic units, such as phyllites, quartzites with serpentines and chert, and gabbros [70] (i.e. K2p, K2j, K2e, K2i and K2c geological units) .

\subsection{Geometric analysis of the tectonic complex, a Riedel shear system approach}

Faults are as a rule, indicated by lineaments [33]. Moreover, lineaments are generally associated with faults and linear zones of fracturing, indicating deformation patterns which may be expressions of a certain tectonic regime. Furthermore, geometric characteristics of faults and lineaments reflect the tectonic motions that have been occurring recently over an area.

A semi-qualitative approach called Riedel Shear System, was applied in order to understand the geometric relations between faults and lineaments in the Upper Guajira [29,126-128]. Riedel structures were obtained for each physiographic subregions and for the whole Upper Guajira region based on the geometry of the rose diagrams. Riedel shears are subsidiary shear fractures that propagate a relatively short distance out of the major fault, being coeval with it. The geometrical arrangement of Riedel shears indicates the sense of movement within the main wrench zone, widely used to interpret the kinematic evolution.

The basic geometry of the Riedel structures consists of conjugate shear bands denoted by R and R'. R-bands are synthetic to the sense of the major fault and generally build the most prominent set. They develop at an acute angle $\left(15^{\circ}\right)$ clockwise to a sinistral main fault or anticlockwise to a dextral main fault. R' -bands are antithetic faults oriented at high angle $\left(75^{\circ}\right)$ conjugate with R-bands. The R- and R'-bands create an angle of about $\theta / 2$ and $90^{\circ}-\theta / 2$ to the general shear-zone direction, respectively, and intersect in an acute angle of $\beta=90^{\circ}-\theta$, where $\theta$ is the angle of internal friction $[127,129,130]$.

The Caribbean plate shows a dextral oblique movement with respect to the South American plate in northern Colombia, producing the strike-slip faults of OF and CF (Fig 1B). The deformation features are organized in a set of structures over or near the wrench zone that may form simultaneously, and which are geometrically oriented by the horizontal strain-ellipse, which are supposed to occur at $45^{\circ}$ in regard to the strike-slip major fault. Thus, the displacement of the $\mathrm{CF}$ produced a set of structures such as folds and thrust (in a direction perpendicular to the SHmax), normal faults and tension fractures and Riedel structures (in a direction parallel to the SHmax), all of them interacting in a geometrical arrangement.

The present-day stress field shows how pre-existing faults can be reactivated, controlling the deformation of 
younger units. As explained above, the study area is characterized by a compressive maximum horizontal stress (SHmax) with a NW-SE direction, in which the master fault (CF) can therefore be interpreted as a dextral fault. The spatial pattern of lineaments can be interpreted as a dextral simple shear tectonic model. Thus, considering the SHmax with a NW-SE direction and considering the CF strike of $\mathrm{N}^{\circ} 5^{\circ} \mathrm{E}$, the dominant system of NW-SE azimuth lineaments can be interpreted as synthetic dextral R-bands fractures $\left(\mathrm{N} 85^{\circ} \mathrm{E}\right)$. The NNW-SSE azimuth can be interpreted as antithetic sinistral R'-bands fractures $\left(\mathrm{N} 20^{\circ} \mathrm{W}\right)$. Based on the above facts, strain ellipsoids were defined for each area to understand the bulk geometry of deformation to create a model of the general kinematic system of the area (Fig.8). It is important to denote that thrust and normal faults can be also discriminated due to their geometries as well as fracture distributions by using this method, showing the reliability of the Riedel analysis for a big area, such as the Upper Guajira region.

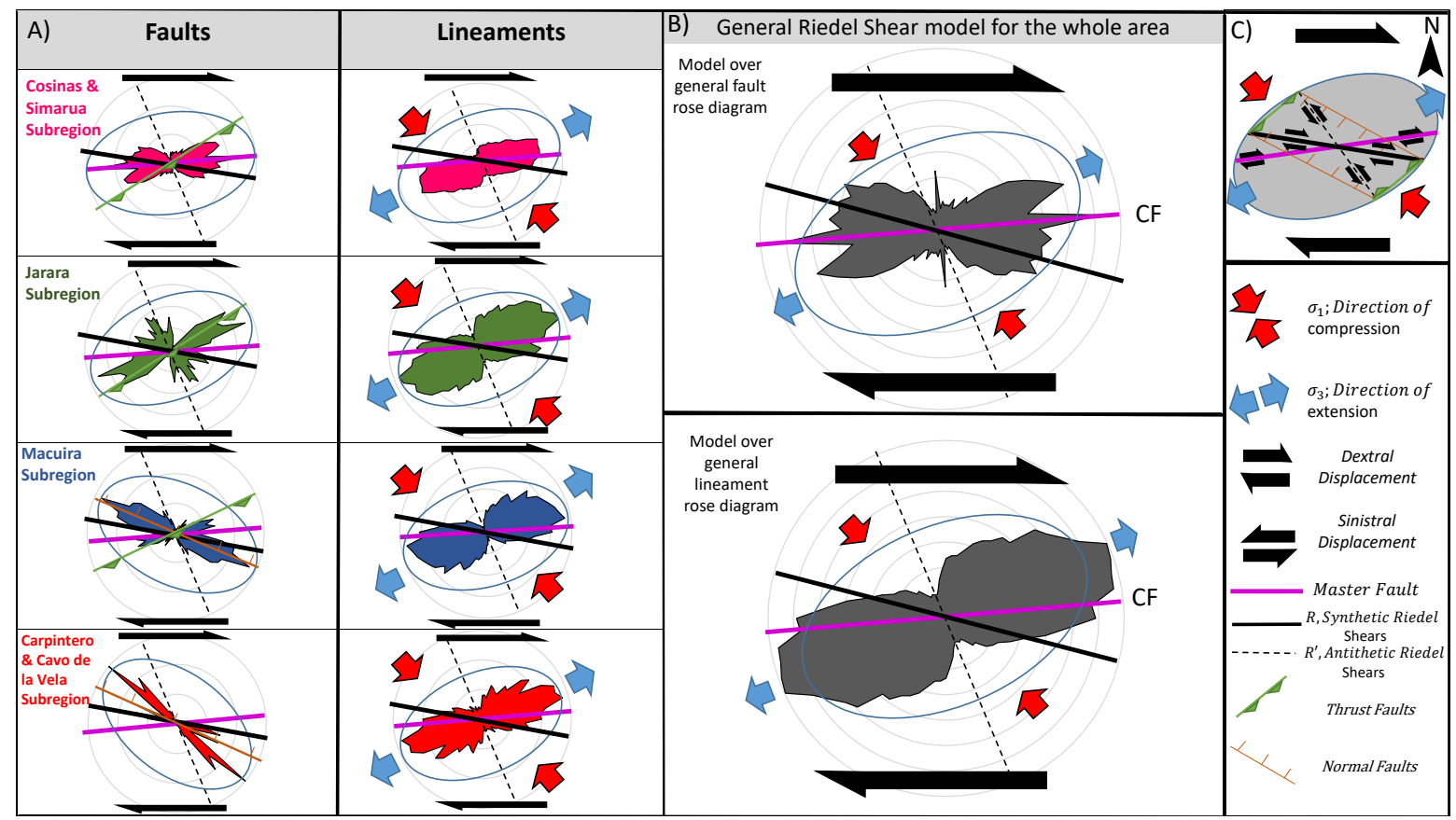

Figure 8. A Riedel shear model over the CF, the master fault. (A) Faults and lineaments for each subregion, showing typical structural features related to the transpressive regime. (B) Faults and lineaments for the whole area, depicting directions of a Riedel model features. (C) Present-day stress tensors characterized by a principal compressive axis striking NW-SE, leading to a dextral movement along the $\mathrm{CF}$.

\subsection{Lithological and structural discrimination from multispectral data}

Digital processing of Landsat-8 OLI/TIRS images using a variety of composites and enhancement techniques have been tested on selected structural or lithological elements in order to understand the landform and its structures due to the transpressive tectonic system. The Principal Component Analysis composite (PC5, PC3, PC2) has been shown to be accurate and useful for the identification and discrimination of lithology and structural features [48]. We used the geological map to better constrain our spectral result. Distinct structures such as faults, fold and particularly the Cuisa strike-slip master fault, in where a notorious displacement between geological units can be observed and inferred (Figs.9A, 9a1 \& 9C). It was found that the CF is highly enhanced and shows a good lithological discrimination in the PCA composite image. Folds near the CF were also identified, showing at the north of the fault the axial surface in NW direction over Neogene limestones and clays (E3s), and at the south of the fault an axial surface in a NE trend over Jurassic arcillolites and shales units (J3sc and J1ch) (Fig.9a1). Some structural features such as faults and lithological contacts can be observed in the Jarara subregion, enhancing features related to deformation history of the study area. It was observed, by comparing the geological map of the Jarara area with the PCA combination of this zone, that faults are highly enhanced, especially over the Cretaceous unit (K2j), which is the one that contains this type of fault. Normal faults are also enhanced, 

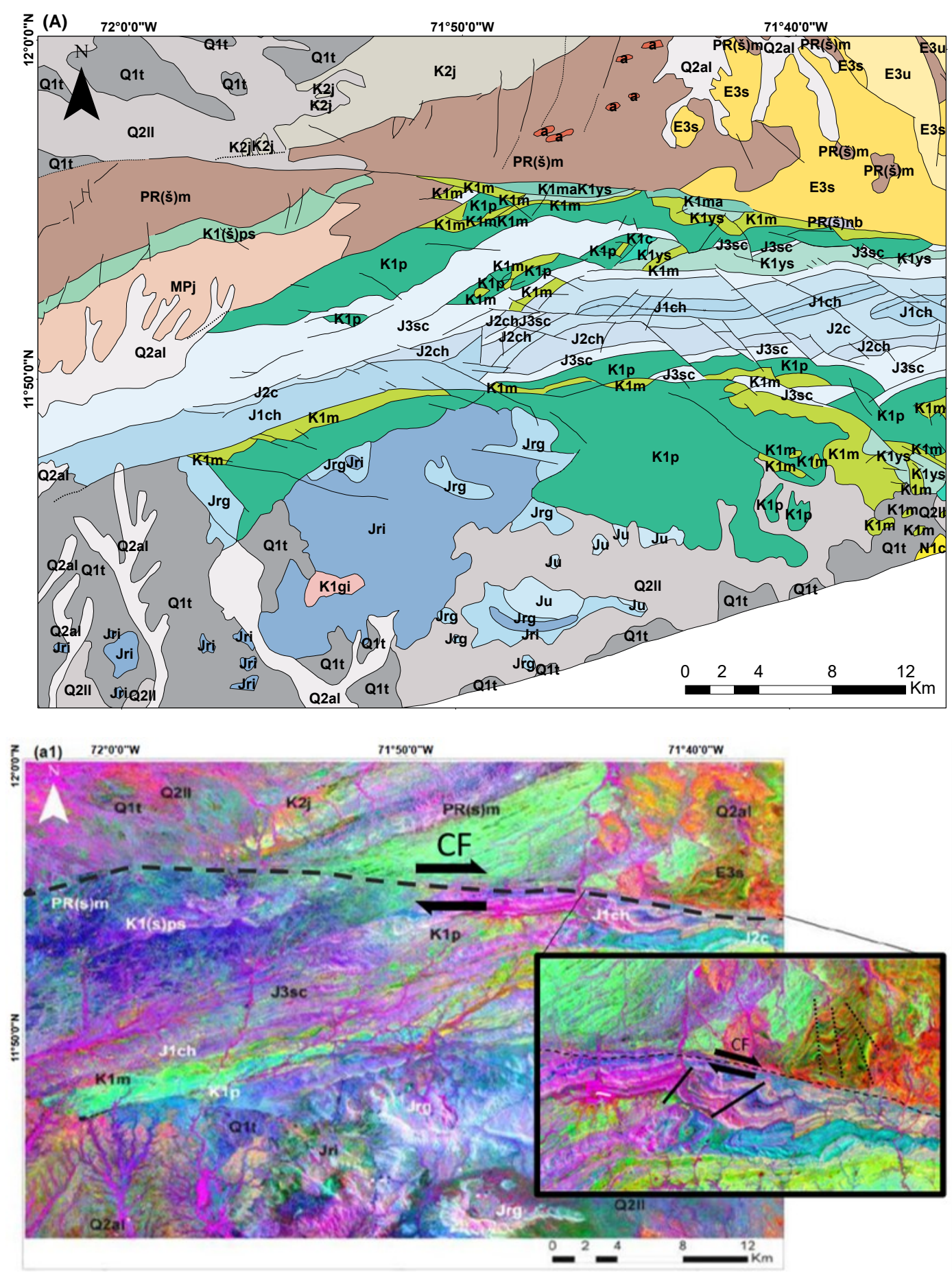
(B)

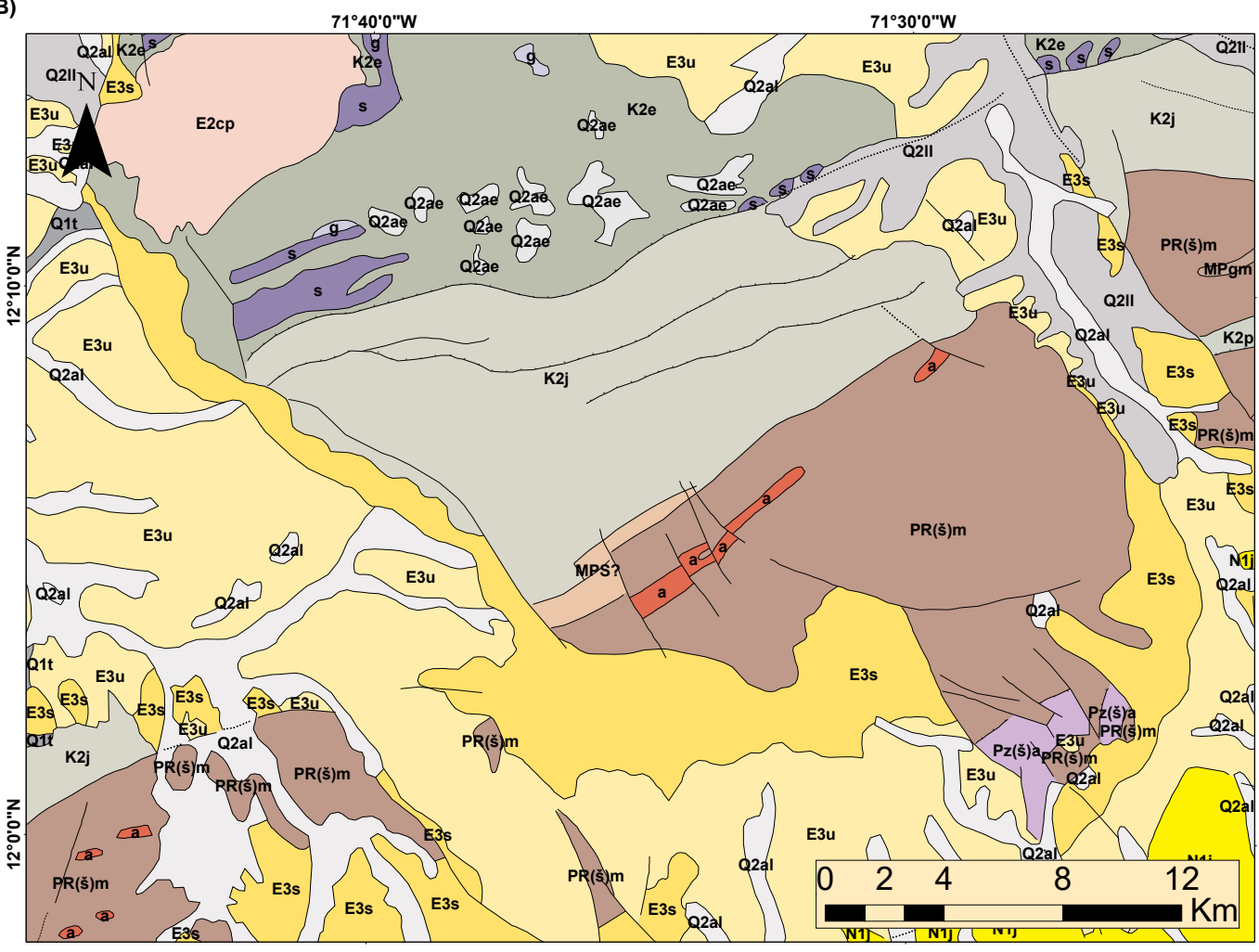

b1)

$71^{\circ} 40^{\circ} 0^{\circ} \mathrm{W}$

$7^{\circ} 30^{\circ} 0^{\circ} \mathrm{W}$

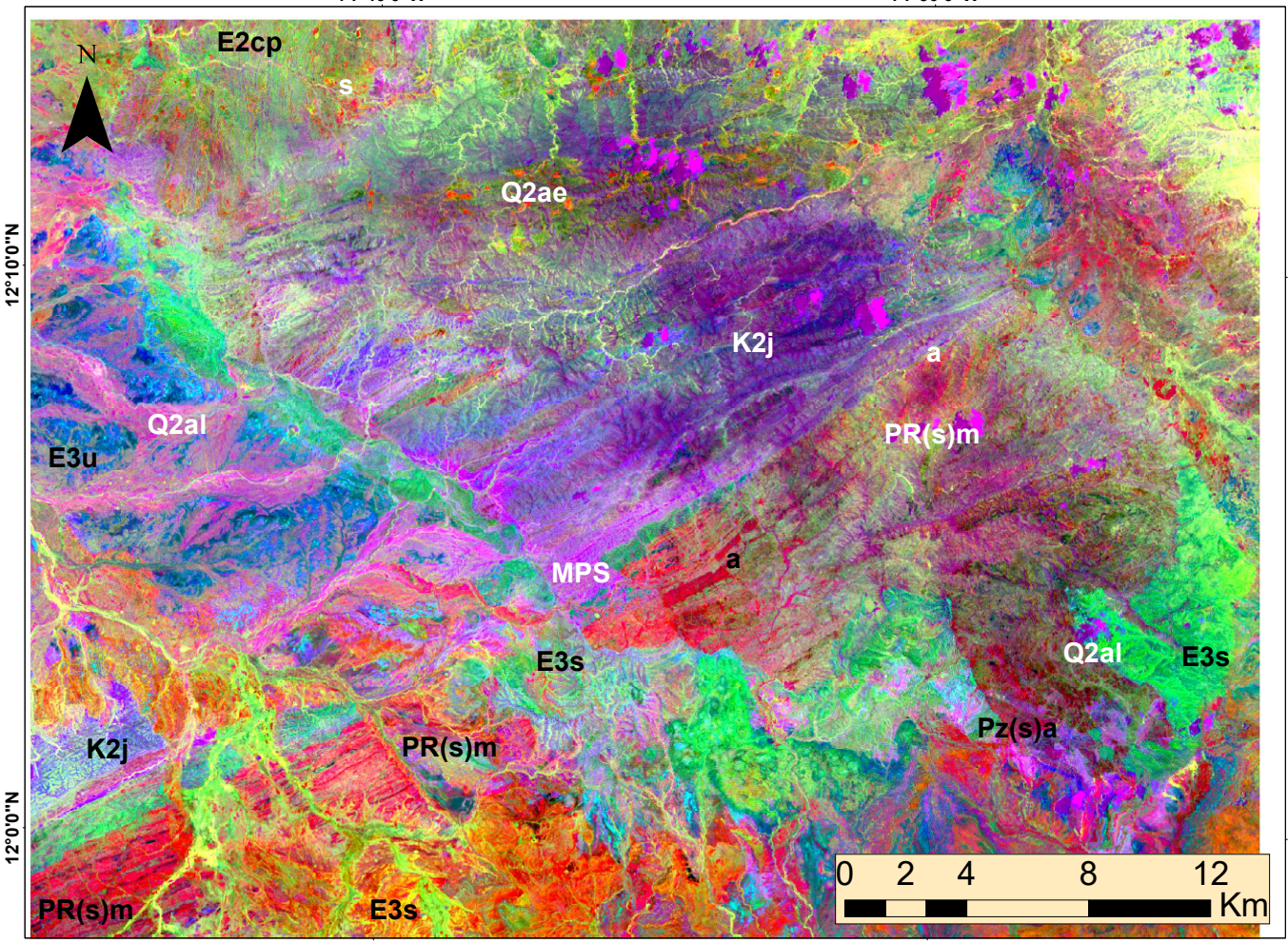




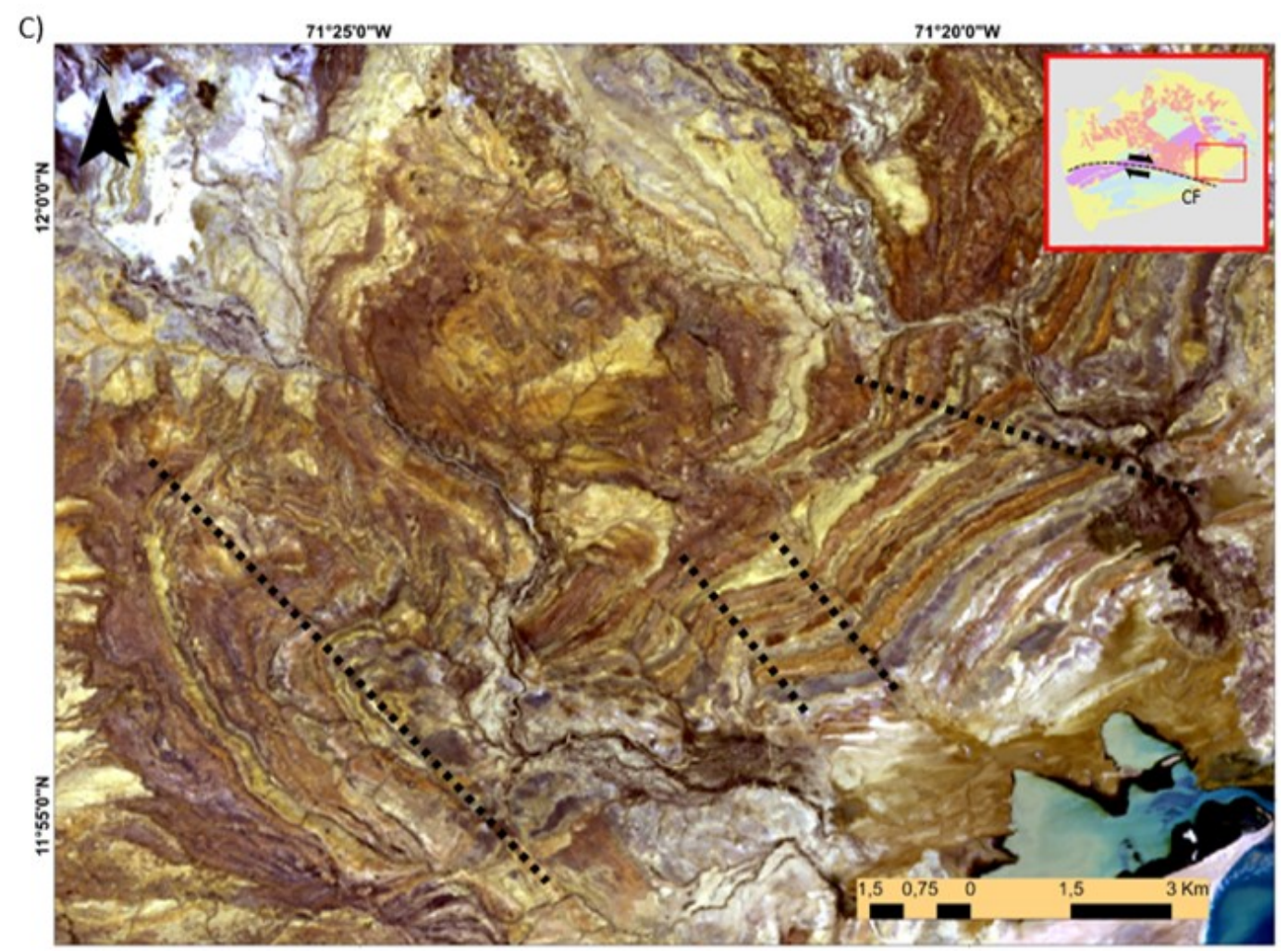

Figure 9. Combination bands from Landsat- 8 and geological map over specific areas. A) Cosinas and Simarua area, exposing a high correlation between the geological map and the 532-PCA combination scene. a1) A Conspicuous view of folds due to the CF strike-slip deformation, black lines show the NE direction axial planes of the folds at the south of the CF, whereas black doted lines show the NNW direction axial planes of the folds at the north of the CF. The significant geological units recognized in this area are Proterozoic gneisses and feldspathic quartz schists as PR(s)m, Jrg, Jurassic arcillolites J1ch, Jurassic shale (J3sc) Cuisa shale, Cretaceous carbonates and shales as K1m, Cretaceous sandstones and conglomerates with high fauna as K1p, Paleogene carbonate sandstones as E3s, Quaternary poorly consolidated sandstones as Q1t, Quaternary alluvial deposits as Q21l and Q2al. B) Jarara region showing a good correlation between the geological map and b1) the 532-PCA scene. The geological units recognized in this area are the Proterozoic PR(s)m unit, the Proterozoic marbles and metasedimentites as $\mathrm{Pz}(\mathrm{s}) \mathrm{a}$, Proterozoic Jojocinto granofels MPS, Proterozoic amphibolites (a), Cretaceous serpentinites (s), and alluvial deposits as Q2al. C) 432 band combination of a recent sedimentary basin over the SE zone of the study zone, exposing significant deformation in younger lithologies, as it can be observed in the direction axial plane of the folds, represented as black dotted lines with a NNW direction of the fold axial planes of the at the north of the western zone of the CF. For more information about geological units check Rodríguez and Londoño, 2002 research [70]. 
delimiting lithological units, and showing a geometrical position similar to those seen in the geological map. Proterozoic units (PR(s)m and MPS geological units) are highly enhanced in the PCA composite image (Fig.9B \& 9b1). A sedimentary basin in the southeast of the study area was also identified using the Landsat band composite (432) (Fig.9C). According to the geological map [70] (Fig.1C) the area exposed consist mainly by arcillolites and alluvial deposits with ages ranging from Neogene to Quaternary; located at the north of the western zone of the CF, being highly folded as it was showed over the Cosinas and Simarua zones (Figs.9a1), and denoting that the axial traces of the folds to the south of the CF (Figs.9a1) show similar NE orientation similar to the preferent lineament azimuthal trends, whereas the axial trace of folds to the north of the CF resembles a NNE trend more like R'-band Riedel shears (Fig.9C), suggesting that CF is still active by highlighting deformation structures over Jurassic to Neogene units from multispectral composite images. This pattern coincides with the dextral movement of the master CF.

\subsection{Drainage Network analysis}

\subsubsection{Morphometry and morphology of drainage Networks}

The drainage network consists of 44568 streams organized into 5 stream orders, according to the Strahler order [131,132]. Table 4 shows that the Stream order seems to increase at the same rate as the average length increase; except for the III order stream, which shows a slight deviation from what is expected. The general drainage frecuency density and length density over the Upper Guajira region is $5,83 \mathrm{No} / \mathrm{km}^{2}$ and respectively $0.85 \mathrm{Km} / \mathrm{km}^{2}$ [133]. Drainage network results from variations in the porosity, topography, geology, structure

\begin{tabular}{|c|c|c|c|}
\hline $\begin{array}{c}\text { Stream } \\
\text { Order }\end{array}$ & $\begin{array}{c}\text { Number of } \\
\text { Stream }\end{array}$ & $\begin{array}{c}\text { Total lenght } \\
\text { of streams } \mathbf{( K m})\end{array}$ & $\begin{array}{c}\text { Average stream length } \\
\text { of streams } \mathbf{~ K m})\end{array}$ \\
\hline I. Order & 23516 & 3383.37 & 0.143 \\
\hline II. Order & 11629 & 1738.33 & 0.149 \\
\hline III. Order & 6381 & 936.84 & 0.146 \\
\hline IV. Order & 2523 & 400.57 & 0.158 \\
\hline V. Order & 519 & 83.08 & 0.160 \\
\hline
\end{tabular}

Table 4. Morphometric drainage network characteristics of the Upper Guajira.

and chemical composition of soils and rocks [134], which means that the drainage pattern records evidence of tectonic deformation [28,29,134,135]. In that way, drainage patterns are normally controlled by the tectonic activity, creating anomalies along the surface [136]; therefore, drainage anomalies analysis provide valuable information on the actual tectonic deformation.

Drainage networks have been classified in a variety of studies, as it was done in this research (Fig.10) [28,29,134, 136]. The dendritic pattern is the most common pattern along in a network, and is located in the flattest areas. Dentritic patterns have a treelike branching system, which consists of the junction of channels that flow in the same direction, but the branches are oriented in several directions [134]. Generally, this type of pattern occurs in flat-lying rocks, meaning that they do not have a significant structural or slope influence [29,137].

Parallel drainage patterns were also found, particularly in the SE hillside of the Macuira serrania and formed in areas where the water flow is highly controlled, indicating a zone with flat lowlands. Elongated forms are also found in areas of parallel landforms [136] such as the valley between the Macuira and Jarara serranias, where the Macuira fault separates the Jarara and Macuira serrania. Angular patterns are also found in the NE slope of the Macuira serrania, where the slopes are steep. This kind of pattern shows a transition from angular to dendritic patterns to the north. Annular patterns are less common than patterns mentioned above and reveal the influence of primary streams developed in a semi-concentric circular domelike hills on sedimentary rocks [134,136], such as in the Carpintero serrania. These patterns are probably associated with the accretion of the Ophiolites on the Late Cretaceous, as discussed above. To validate the drainage network extracted from the SRTM DEM, the rivers 

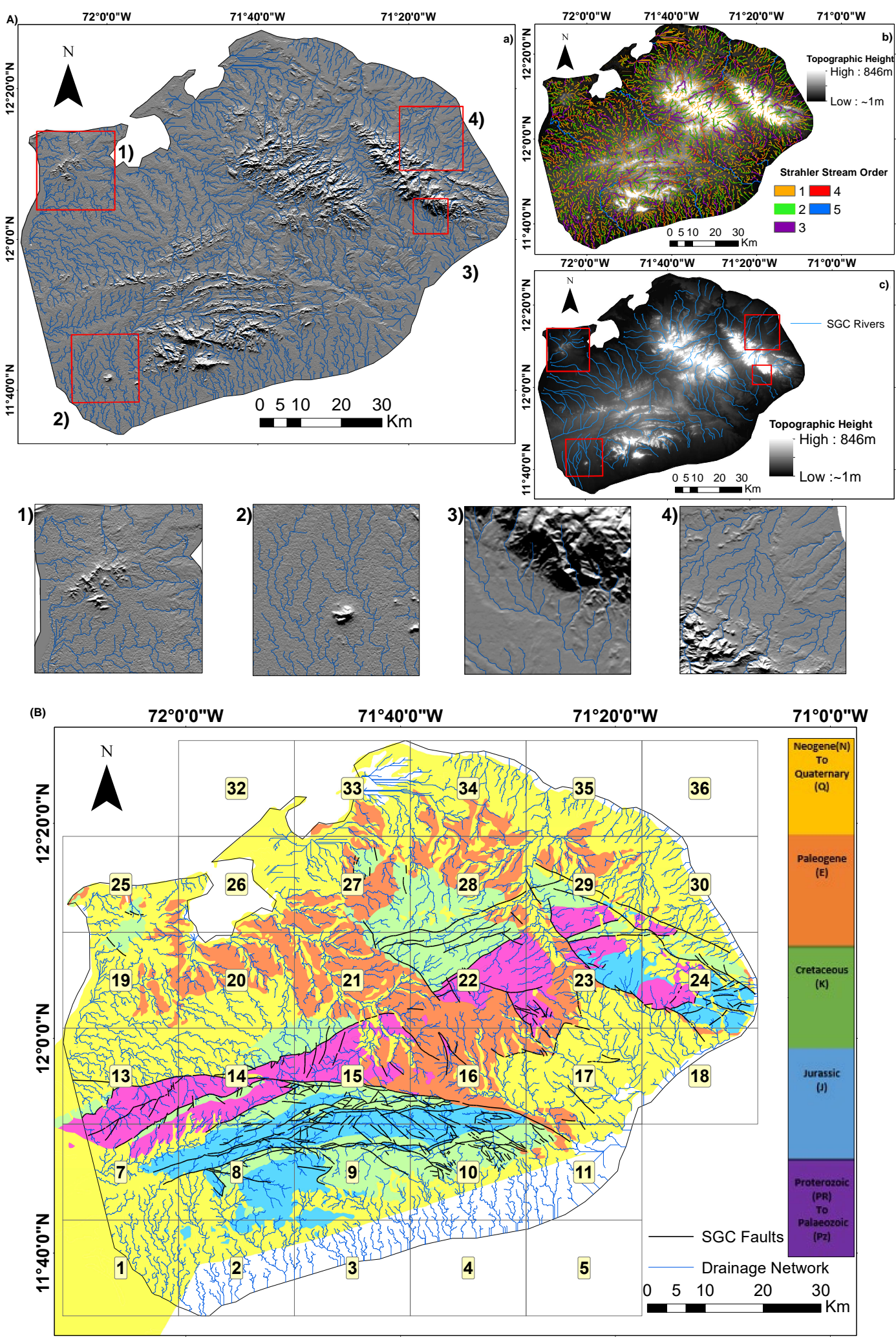

Figure 10. Drainage network of the Upper Guajira zone. A) a) Surficial stream network of the study area derived from the SRTM DEM. The drainage channel is enhanced in a dark blue solid line superimposed in a hillshaded image. b) Map showing the distribution of streams according to the Strahler order. 3) Tributaries extracted from the SGC geological map. Different drainage patterns in the study area: 1: Annular, 2: Dendritic, 3: Parallel and 4: Angular. B) Combination of the drainage network and geological units, splitted by grid domains. 
from the geological map were also used. The comparison shows that the morphology of the patterns between the extracted streams and the ones from the map are very similar, corroborating our results.

\subsubsection{Drainage network density analysis}

A density frequency map (No.streams $/ \mathrm{km}^{2}$ ) was done for the extracted drainage network (Fig.11A). A visual interpretation of the map shows that the zones with higher concentrations of drainages correspond to the plane zones that surround the nearby serranias. Moreover the combination of density and geological map that higher concentrations of drainage patterns are located over Paleogene(K), Quaternary(Q) and Neogene(N) lithotypes. With the use of the Buffer Tools on ArcGIS we classified the length of streams under the influence of lineaments in order to estimate the streams controlled by lineaments. Both lineament combinations from the SRTM data were buffered with the streams by using a $150 \mathrm{~m}$ threshold. All the streams within the buffer zone were extracted and density and analysis of the segments was performed (Fig.11B). Results showed that about $1652.49 \mathrm{~m}(25 \%)$ of the streams are influenced by lineaments. From the streams influenced by SRTM lineaments, $49 \%$ correspond to the first-order samples, and about $30 \%, 15 \%, 4.48 \%$ and $1.52 \%$ influence was found in second, third, fourth and fifth orders respectively (Fig.11B) .

These results indicate that most of the influence occurred within the first order streams, which suggests that the impact of lineament is strong in the areas that have steepest slopes and rough terrain (Fig.11B). The dominance of lineament over the streams is diminished over the sedimentary basins in where streams do not seem strongly dominated by tectonic activity.

\subsubsection{Domain analysis of drainage network and aligned morphological features}

A detailed analysis of azimuth stream channels was performed with GIS tools on individual domains. As for the lineaments and faults, every stream channel was segmented in straight lines (i.e. between two vertexes) in order to use rose diagrams to calculate its preferential azimuth direction. The line segments corresponding to streams were weighted by their azimuth frequency. 10 grid domains covering the area were analyzed (Figs.10A $\& 12$ ). The grids were chosen selecting the ones with a significant quantity of linear features within their area. Hence, Domains 8, 9, 10 are in the SE of the zone, the 14,15,16 domains are within the middle part and the remaining four $(22,23,24$ and 29) are in the NE sector. For each picked grid, faults and SRTM lineaments frequency diagrams were constructed as well. A structural and tectonic control of the drainage network along the study area is observed.

The drainage networks tend to have azimuthal direction in all directions, especially in intervals of $45^{\circ}$. Nevertheless, the interest of decipher the principal azimuthal trends of the streams is to observe if there is a relation with the morphological trends, such as faults and lineaments. Table 5 show the principal azimuth trending that linear samples have over each domain.

The NE-SW and E-W trends are the most common directions of linear features. Domains 8 and 24 are the ones that present identical azimuth trends (Table 5). These domains may be zones where tectonic activity has a stronger influence over the streams and lineaments. Domains 15 and 29 have similar percentages of NE-SW and E-W trends, indicating a pos tectonic influence of lineaments or faults within these domains. Particularly, domains 8 and 15 are similar, as are the 24 and 29 domains.

The E-W trend dominates in domains 9, 14 and 23, with all three showing the NE-SW direction as their second most common trend. Only domain 22 has NE-SW as the most similar trend of the linear features. Domains 10 and 16 present a common grid boundary and higher frequencies in the NW-SE direction, with the peculiarity that both present less similarity in the NE-SW trend.

\subsubsection{Regional analysis of the drainage network}

Examining only the higher order channels (i.e. 4th and 5th order), the zone is drained by five main streams: The Masayumachama in the NE sector, the Itapara draining in the north and the Silimahana draining at south; both in the middle sector of the study area, and the Urash and Manash in the SW sector (Fig.13). The Northern stream flows from SW-NE, starting its path in the Jarara serrania, bordering the Macuira serrania until the Caribbean Sea. The slope degree map (Fig.13) shows that the principal flow paths of the selected tributaries 

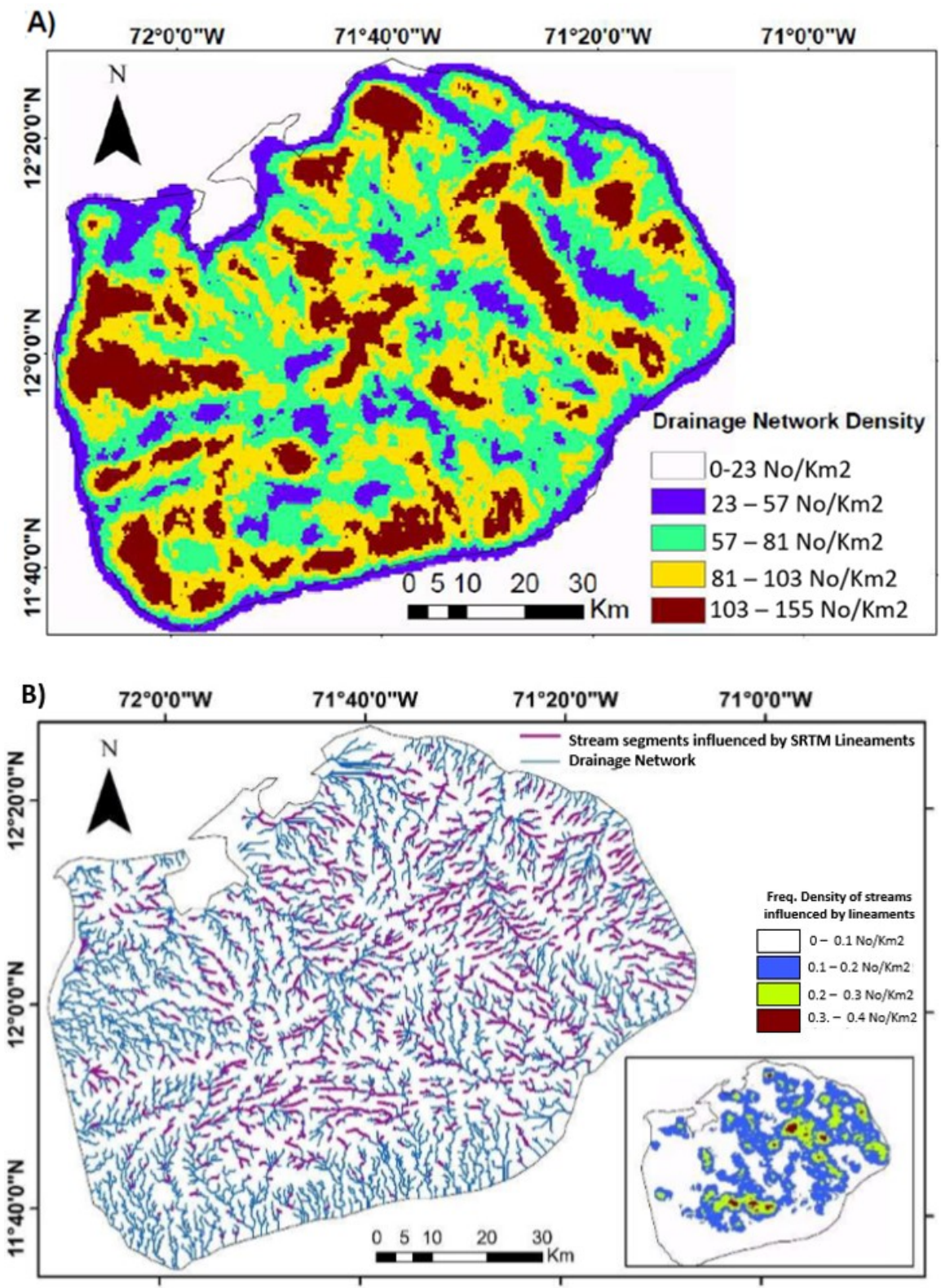

Figure 11. A) Drainage density map with radius of $1 \mathrm{~km}$, showing high density values of streams over flatness areas. B) Streams influenced by SRTM lineaments. Violet colored segments of streams are controlled by available lineaments in the study area. A density map of the controlled streams showing control of lineaments over the streams is exposed here.

are above the areas with lowest slopes, and from this raster were extracted the different slope measures of the tributary paths. Table 6 show the morphometrical results of the selected tributaries.

Gradient variations along the biggest streams can be identified by analyzing their path profiles, highlighting drainage anomalies $[100,104,138,139]$. These anomalies are commonly known as knickpoints, which generally correspond to the terrane response of climate changes, lithological variability, changes in the stream power and/or tectonic deformations $[29,40,139,140]$. Therefore, the study of longitudinal profiles gives information on the part over the streams that undergo higher influence due to the lithology and/or the tectonic environment. Is important to consider that these measures disregard factors such as stream power or climate changes. Another aspect to bear in mind is that the origin of knickpoints may not always be possible without a detailed investigation (Figs. $13 \& 14)$.

Figure 14 shows longitudinal profiles of the five picked tributaries, labeled form A to $\mathrm{E}$ as seen in table 6 . As expected, these profiles have different and variable curves and gradients. The slope changes vary from $0^{\circ}$ to $20^{\circ}$ 

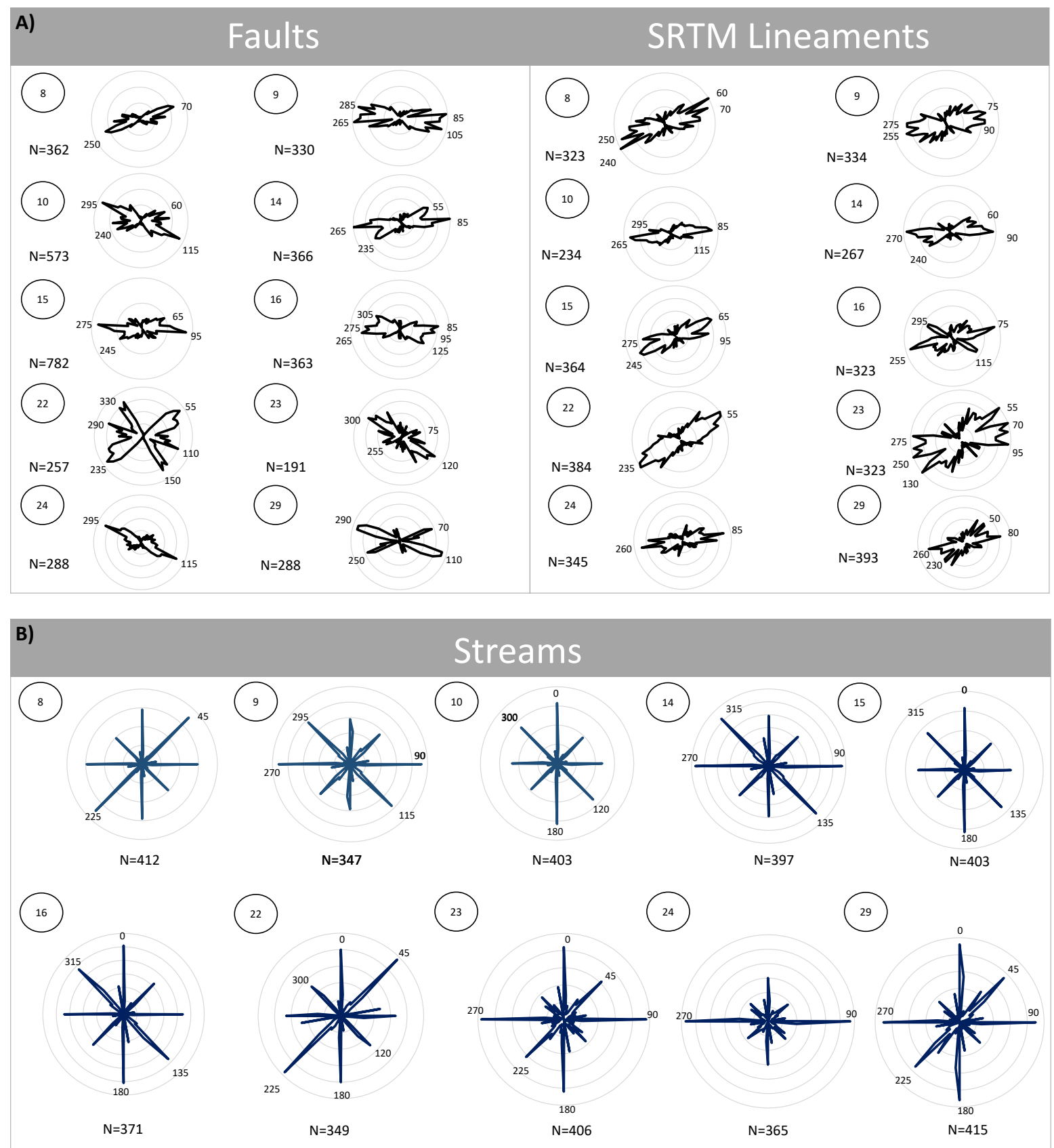

Figure 12. Frequency rose diagrams of selected domains. A) Frequency rose diagrams of faults and SRTM DEM; B) Frequency rose diagram of streams.

all over the zone. Longitudinal profiles of the stream A have the higher slope values in its first $24 \mathrm{~km}$ of length, where the path crosses over a highly faulted and deformed zone. Since the path pass the $24 \mathrm{~km}$, the river starts to flow parallel to the $\mathrm{CF}$, surrounding the Jurassic volcanic units over the Cosinas serrania. Beyond the $24 \mathrm{~km}$ of path, knickpoints are not well highlighted.

Stream B is about $10 \mathrm{~km}$ to the east of stream A. Profiles show a better enhancement of knickpoints that in the stream A, even when both cross over a highly faulted zone. There are three knickpoints that could be easily discriminated by this remote sensing analysis, the first two possibly being caused by the smooth but strong changes in elevation and the last knickpoint may be related to the tectonic arrangement at $20 \mathrm{~km}$ along the path, where a high concentration of faults are located. 


\begin{tabular}{|c|c|c|c|}
\hline $\begin{array}{c}\text { Grid } \\
\text { Domain }\end{array}$ & $\begin{array}{c}\text { Azimuthal } \\
\text { trends of } \\
\text { sreams }\end{array}$ & $\begin{array}{c}\text { Azimuthal } \\
\text { trends of SRTM } \\
\text { lineaments }\end{array}$ & $\begin{array}{c}\text { Azimuthal } \\
\text { trends of } \\
\text { faults } \\
\end{array}$ \\
\hline 8 & I)NE-SW & I)NE-SW & I)NE-SW \\
\hline 9 & $\begin{array}{c}\text { I)E-W } \\
\text { II)NW-SE }\end{array}$ & $\begin{array}{l}\text { I)NE-SW } \\
\text { II)E-W }\end{array}$ & $\begin{array}{c}\text { I)E-W } \\
\text { II)NW-SE }\end{array}$ \\
\hline 10 & $\begin{array}{c}\text { I)N-S } \\
\text { II)NW-SE }\end{array}$ & $\begin{array}{c}\text { I)E-W } \\
\text { II)NW-SE }\end{array}$ & $\begin{array}{l}\text { I)NW-SE } \\
\text { II)NE-SW }\end{array}$ \\
\hline 14 & $\begin{array}{c}\text { I)E-W } \\
\text { II)NW-SE }\end{array}$ & $\begin{array}{c}\text { I)E-W } \\
\text { II)NE-SW }\end{array}$ & $\begin{array}{c}\text { I)E-W } \\
\text { II)NE-SW }\end{array}$ \\
\hline 15 & $\begin{array}{c}\text { I)N-S } \\
\text { II)NW-SE }\end{array}$ & $\begin{array}{l}\text { I)NE-SW } \\
\text { II)E-W }\end{array}$ & $\begin{array}{c}\text { I)E-W } \\
\text { II)NE-SW }\end{array}$ \\
\hline 16 & $\begin{array}{c}\text { I)N-S } \\
\text { II)NW-SE }\end{array}$ & $\begin{array}{l}\text { I)NE-SW } \\
\text { II)NW-SE }\end{array}$ & $\begin{array}{c}\text { I)E-W } \\
\text { II)NW-SE }\end{array}$ \\
\hline 22 & $\begin{array}{l}\text { I)NE-SW } \\
\text { II)N-S } \\
\text { III)NW-SE }\end{array}$ & I)NE-SW & $\begin{array}{l}\text { I)NE-SW } \\
\text { II)NW-SE }\end{array}$ \\
\hline 23 & $\begin{array}{c}\text { I)E-W } \\
\text { II)N-S } \\
\text { III)NE-SW }\end{array}$ & $\begin{array}{l}\text { I)E-W } \\
\text { II)NE-SW }\end{array}$ & $\begin{array}{l}\text { I)NW-SE } \\
\text { II)NE-SW }\end{array}$ \\
\hline 24 & I)E-W & I)E-W & I)E-W \\
\hline 29 & $\begin{array}{c}\text { I)N-S } \\
\text { II)E-W } \\
\text { III)NE-SW }\end{array}$ & $\begin{array}{l}\text { I)E-W } \\
\text { II)NE-SW }\end{array}$ & $\begin{array}{l}\text { I)NW-SE } \\
\text { II)NE-SW }\end{array}$ \\
\hline
\end{tabular}

Table 5. Preferential azimuthal directions of the streams, SRTM lineaments and faults in the selected domains.

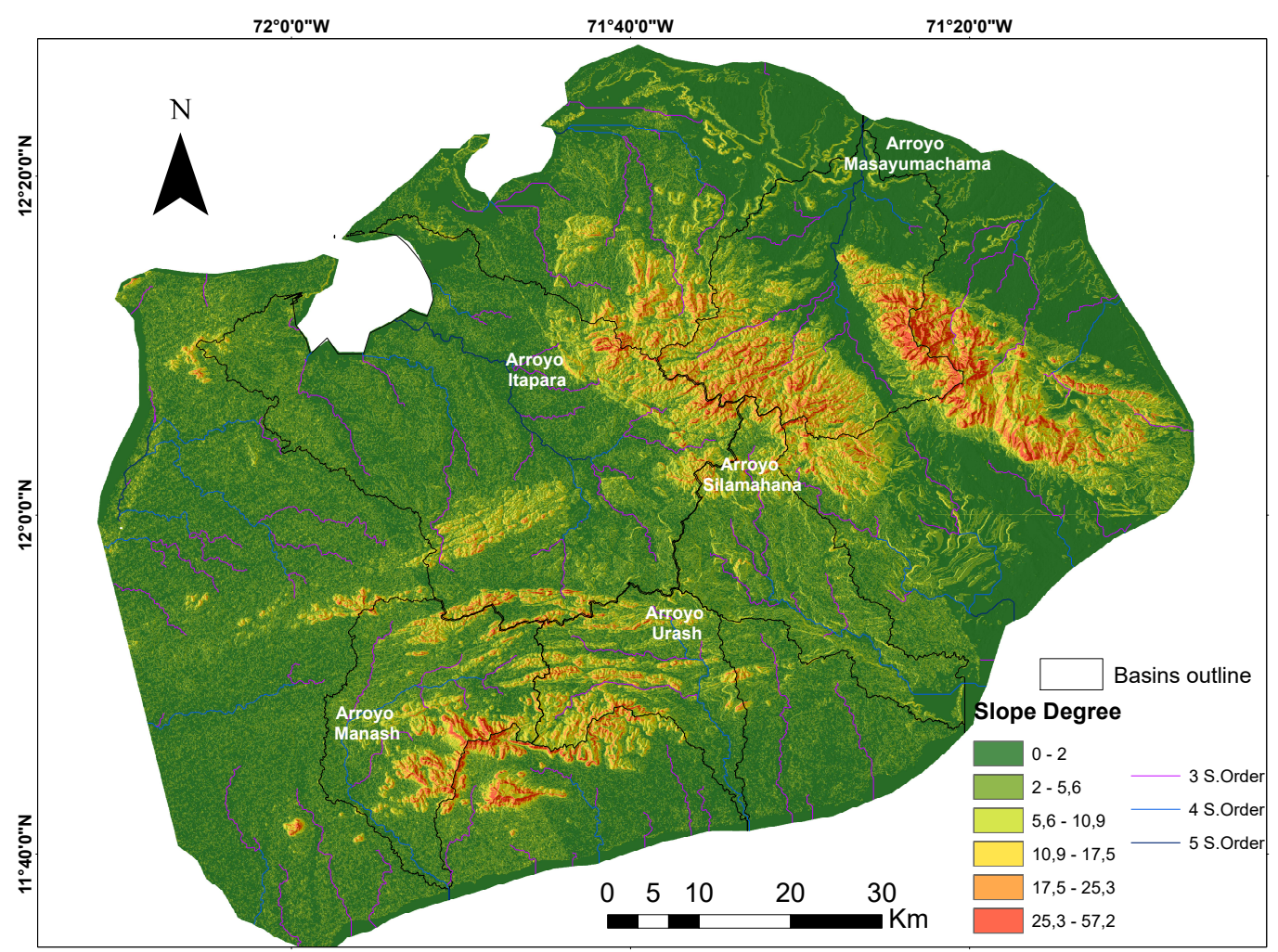

Figure 13. Delimited basins that contain principal streams of the Upper Guajira according to the Strahler Order of the tributaries, superimposed on a Slope Degree map that enhance zones with higher deformations that the low slope degree regions highlighted in green.

Stream C starts its pathway in the SW foothill of the Jarara serrania, and is about $4 \mathrm{~km}$ east of stream B in the middle of its path. Knickpoints are located in the first $5 \mathrm{~km}$ where the topography starts to decrease. Other 
changes in slope or elevation may not be related to tectonic activity, but to erosional processes. The tributary at $30 \mathrm{~km}$ starts to follow the path trace of the CF.

Stream D its about $6 \mathrm{~km} \mathrm{NW}$ of stream C. The steepest slopes are in the first $5 \mathrm{~km}$ where the faults are interacting, and the topography is decreasing faster. The tributary is sourced in the NW foothills of the Jarara serrania. Other recognizable knickpoints are identified at $20 \mathrm{~km}$ of recovery, which could be related to the boundary between recent chronostratigraphic units (i.e.E, $\mathrm{N}$ and $\mathrm{Q}$ ages).

Stream E is about $9 \mathrm{~km} \mathrm{NE}$ of stream D. This tributary receives water from the Jarara Serrania in the SW and the Macuira in the SE. At $10 \mathrm{~km}$ the tributary shows a singular knickpoint related to fault interactions. Between the $15-20 \mathrm{~km}$ there is an irregular pattern which coincides with the boundary between $\mathrm{E}$ and $\mathrm{N}$ Units.

One of the most important results of the previous analysis is the tendency of the CF to determine the paths of tributaries (A, B and C). The drainage anomalies, along longitudinal profiles that cross over or near to the main fault (CF) give clues about neotectonic activity. These anomalies suggest that the CF is active. Some GPS studies demonstrate a dextral movement along the coast. Thus any displacement of CF induces the activation of the tectonic system, so that it produces changes in the ground surface of the stream pathway, even if there is not a discernible morphological expression. Tributaries D and E show anomalies over their profiles with knickpoints at the where the stream cuts across a fault. The lithologies cross by this tributaries ranged ages from Paloegene to Neogene, according to the SGC Geological map.

\begin{tabular}{|c|c|c|c|c|c|c|c|c|c|c|}
\hline \multirow{2}{*}{$\begin{array}{c}\text { Main } \\
\text { tributary }\end{array}$} & \multirow{2}{*}{ Code } & \multicolumn{3}{|c|}{ Elevation (m) } & \multicolumn{3}{|c|}{ Slope } & \multirow{2}{*}{$\begin{array}{l}\text { Area } \\
\left(\mathrm{km}^{2}\right)\end{array}$} & \multirow{2}{*}{$\begin{array}{c}\text { Density } \\
\left(\mathrm{km} / \mathrm{km}^{2}\right)\end{array}$} & \multirow{2}{*}{$\begin{array}{c}\text { Tributary length } \\
(K m)\end{array}$} \\
\hline & & Min & Avg. & Max & Max. Degree & Mean Degree & Min. Degree & & & \\
\hline Manash & $\mathrm{A}$ & 0 & 57 & 125 & 10.81 & 1.98 & 0.218 & 571.2 & 0.07 & 44.5 \\
\hline Urash & B & 0 & 43 & 110 & 15.62 & 2 & 0.22 & 455.7 & 0.09 & 42.3 \\
\hline Silimahana & $\mathrm{C}$ & 0 & 59 & 200 & 15.29 & 1.99 & 0.27 & 609.3 & 0.06 & 40.3 \\
\hline Itpara & $\mathrm{D}$ & 0 & 50 & 155 & 8.27 & 1.44 & 0.1 & 958.5 & 0.045 & 43.7 \\
\hline Masayumachama & $\mathrm{E}$ & 1 & 24 & 63 & 7.14 & 0.66 & 0 & 787.4 & 0.03 & 27.5 \\
\hline
\end{tabular}

Table 6. Morphometric results from studied effluents, highlighting the main terrain measurements of the the effluent trajectories over the Upper Guajira peninsula.

\section{Discussion and Conclusions}

\subsection{Surface geomorphological features Vs. Subsurface structures, Tectonic Implications}

Extracted lineaments from remote sensing datasets allowed us to identify several populations of lineaments with various lengths and orientations. Two main orientations were found: I) NE-SW and II) E-W. The lineament samples were mapped and analyzed in several ways such as density maps or rose diagrams, which enhanced the recognition of structural features such as the $\mathrm{CF}$ and structures related to a transpressive system in the zone. High lineament density zones over the density maps are generally related to zones of high topographic relief (i.e. physiographic subregions) and high fracture zones, moreover due to most of the high density areas are not covered by Quaternary and Neogene surficial deposits, the linear structural features of older geological units can be easily detected, allowing to observe older deformations over those units.

The Upper Guajira exhibits different geological units and several prominent structures. Lineaments can provide relative constraints on the evolution of the zone by organizing them according to the geological units of different ages that are crossed by lineaments. All the extracted lineaments from remote images were grouped according to the age of the host rock. Our results show that the NE-SW trend continued from the Precambrian to Quaternary unit; in the Cretaceous age, the NE-SW trend becomes more prominent because the evolution converges from the late Cretaceous onward due to the drifting by the North America and South America plates since the late Jurassic $[3,4,7]$. The E-W trend is better documented from the Paleogene formations. It was during this period that the $\mathrm{CF}$ began to displace the Upper Guajira block from the SNSM-Lower Guajira block [74]; then the Guajira Peninsula started its northeastward translation, which may explain its current geographical position, despite having been formed tens of kilometers away [141]. The E-W azimuth trend also affected all exposed rocks from Precambrian to Quaternary, but it is very conspicuous in the Paleogene.

Neogene to Quaternary units expose a similar azimuth trend, but a noteworthy point is that during these periods 

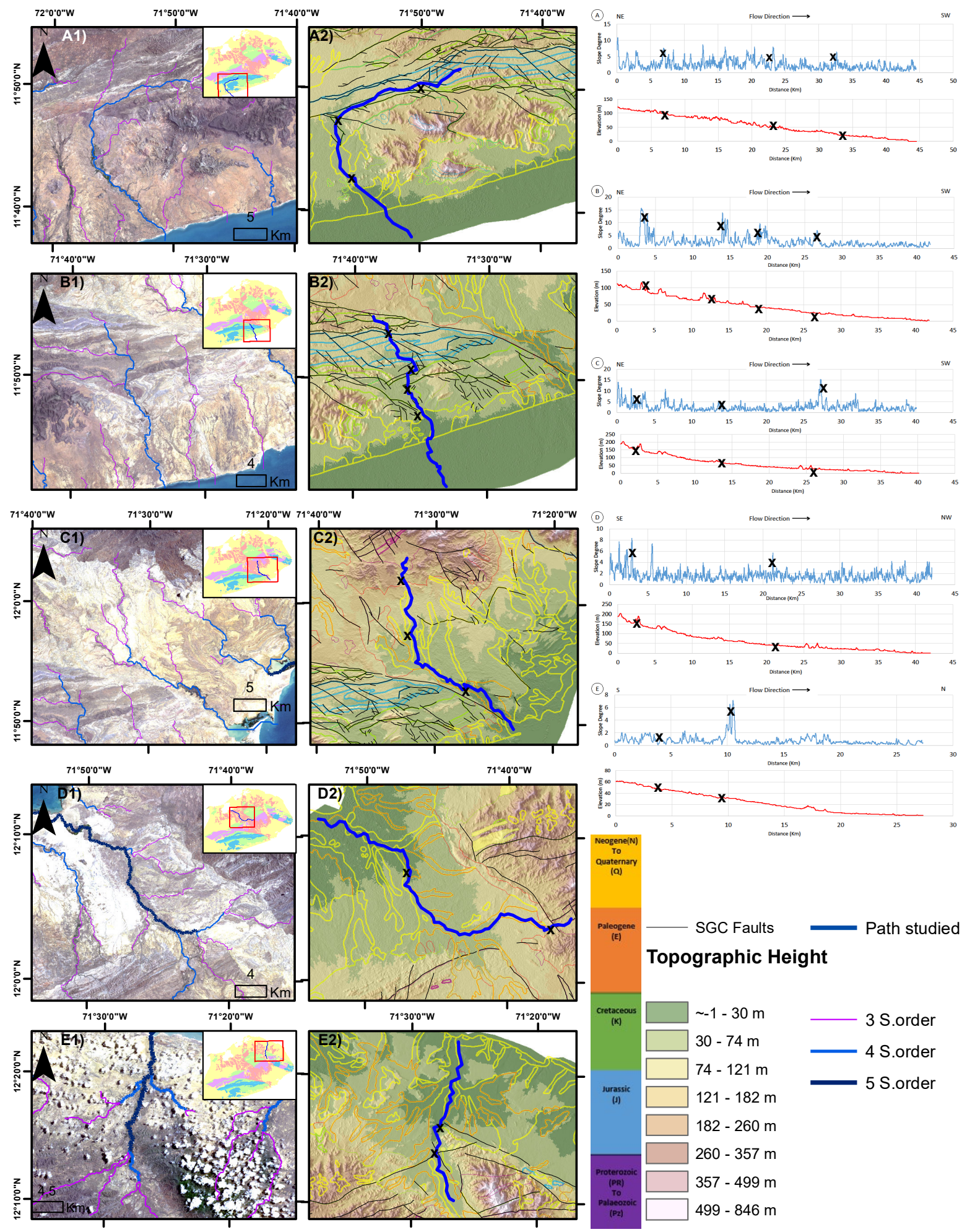

Figure 14. Longitudinal and cross section tributary channels profiles in the Upper Guajira. (A)-(E) Longitudinal profiles of five large tributaries draining into the Upper Guajira. (Refer to figure13 and table6 for tributary name and features). 1: Principal tributaries showing the morphology of the drainages according to the Strahler order superimposed in an image of Landsat- 8 with a true color combination in RGB. 2: The Path selected highlight the slope (blue curve) and the elevation (Red curve) profiles. Paths superimposed on altitude map with the SGC faults and the chronological units. All streams have at least one knickpoint that show the deflection near to the confluence with major faults and tectonic lineaments.

the NE-SW azimuth trend was enhanced, compared with the preceding lineaments. The evolution of this trend 
probably represents the lineaments associated with the continued oblique collision of the margin between the Caribbean and South American Plates. Occurrence and relative abundance of prominent trends (NE-SW and $\mathrm{E}-\mathrm{W})$ through geological time is proposed to be generated by repeated activation of pre-existing crustal structures during different tectonic periods as it was previously addressed. We also observe that in spite of the fact that the sedimentary rocks have a large territorial area and a greater population of lineaments, the population density in this type of rocks is the lowest. Cretaceous units are the ones that present higher densities and greater number of lineaments, suggesting that these units present important features of deformation over the area.

Cenozoic tectonic activity in the study zone has been dominated by mainly compressional/strike-slip stress regimes, which produce the reactivation of crustal structures and recent deformation. In order to understand the present-day behavior of structures over the zone, the extracted faults from the geological map and lineaments were organized in a Riedel shear model, using the CF as the major fault. Results show that the current stress field of the area is characterized by a compressive maximum horizontal stress in NW-SE direction, so the spatial pattern distribution of lineaments can be interpreted as fractures related to the dextral movement of the CF. The E-W trending of lineament samples can be interpreted as the most recent ones, being parallel to the major strike fault; The NW-SE trending lineaments can be interpreted as synthetic dextral R-shear fractures; and the NNW-SSE trendings are interpreted as antithetic sinistral $\mathrm{R}^{`}$-band fractures, which are the less discernible family of fractures.

Distinct geomorphological features typical of a transpressional system were portrayed by processing DEM and Landsat- 8 images. Faults, folds and recent folded basins over the study area help to better understand the results generated by the lineament analysis. The current position of these tectonic blocks, together with their tectonic structures and geochronological associations of lithotypes, support a dextral transpressional tectonic regime over the study area that has been suggested for various authors $[3,20,56]$. It is important to denote that we can not assure all digital lineaments have a tectonic nature, however we suggest must of them have a tectonic significance because: 1) the azimuth of lineaments have a strong correlation with the azimuth direction of faults, so the major geological contacts have a NE trend similar to the major trends of lineaments. 2) Another fact is that the detected lineaments are in the areas in where the main faults occur, contrasting the lack of lineaments in the flat areas as it can be seen in the density maps (Figs. 3, 4 and 5). 3) The Riedel shear scheme shows that the principal azimuth of lineaments and faults are in the same orientation as the $\theta_{3}$ tensor (Fig.8). We recommend more future work on the tectonic activity and physical conditions of the Upper Guajira region, by using geophysical data such as the EGM-2008 gravity data and SAR sensor data, with a seismic analysis in order to understand better the actual activity of the faults, specifically for the strike-slip CF.

\subsection{Drainage network implications}

Within the 10 selected domains where a clear drainage orientation is found, the azimuth distributions of streams are similar to those of the lineaments and faults, with few differences in the prevailing directions. In some cases, the lineaments and faults have a secondary NW-SE trend, which is a main trend in the stream distributions; nevertheless, the NE-SW is a conspicuous azimuth trend of various stream paths. This similarity in the azimuthal trends indicates that faults and lineaments are preferred zones for the water movement, because the water runs preferably over tectonic fractures. There are differences in the spatial distribution of lineament and stream densities over the area, showing that the higher density areas of streams are in the planar zones different than the lineament distribution. Streams were organized by a Strahler order showing that most of the drainage influence over the study area is controlled by first order streams, indicating that the tectonic impact over the streams occurred in the physiographic subregions. Distinct drainage patterns may be related to the movement or deformation produced by morphotectonic features and landforms. It was shown that the best correlation between lineament and drainage streams are presented in the zones with higher slopes, but its important to mention that there is necessary to improve this results within the specific basins (Fig.13) and a particular stream path, by using the normalized steepness index (ksn), SL Index and/or hypsometric profiles. 


\subsection{Conclusions}

This study shows the results of a combined use of remote sensing scenes and GIS techniques in order to interpret the complex structures of the Upper Guajira landscape, which has a geological history since the Precambrian age. Samples of lineaments were used to analyze the tectonic complexity of the study area. The analysis of quantity and length of extracted lineaments from eight different azimuth angles shows that results are more precise and accurate than just using one azimuth angle. The present paper reveals that physiographic zones over the study area, which contains the serrania ranges, are characterized by a high lineament density. Consequently, these areas have greater slope changes, groundwater infiltration potential and influence by recent tectonic activity, which implies that these zones should be avoided for engineering constructions, unless a detailed study of the terrane is performed. Major faults are located over the physiographic zones as well.

The azimuth trends of all the groups of lineaments are predominantly in NE-SW and E-W directions, indicating an homogeneous structural deformation of geological units. The analysis of lineaments with regard to the geochronological units highlights of the movement of the Caribbean plate since the Cretaceous. The response of streams to the lineaments and active faults is observed in the form of clear changes in longitudinal profiles, modifying the gradient and stream patterns. Greater influence of lineaments on drainage networks is found on first order streams, characterized by a decrease of the dominance of lineaments as the stream order increases. A general similarity between lineament trends and in the direction patterns of stream segments and surface structural features suggest that the landform and the structural features of the study zone are highly controlled by a tectonic transpressive system. Evolution of lineaments is related to the reactivation of preexisting faults; probably due to the dextral movement of the $\mathrm{CF}$, in response to the stress field. Therefore, NE-SW trends highlight oblique movement of the Caribbean plate under South American plate, whereas E-W trends highlights the rotation of the stress field that allows the CF to be notorious structural feature of the southern boundary of the Caribbean plate. Processing of Landsat- 8 images allowed us to identify and enhance lithological units and landform structures which are related to the tectonic system that has been described. In addition this study provides valuable information that might be significant for the management and development of the region. Thus, our study represents a contribution to the fields of tectonics, structural geology, engineering geology and hydrogeology. Therefore, this study contribute in the knowledge of the morphological arrangement of the Upper Guajira, by exposing a practical guide that analyse different types of remote sensing data with GIS techniques.

\section{Author Contributions}

- Processing of the satellite images J.D

- Writing of the first draft J.D

- Revision and validation of methodology and analysis A.I., J.P

- Conceptualization J.D., A.I., J.P

\section{Funding}

Financing for this project was provided by the Faculty of Sciences, University of the Andes, Colombia, in part through project FAPA PR.3.2014.1641 to JP.

\section{Conflicts of Interest}

The authors declare no conflict of interest.

\section{Acknowledgements}

To Simon Wilde professor associated from Curtin University, western Australia, who collaborated in the revision of the final manuscript corrections. 


\section{References}

1. Flinch, J. F., Amaral, J., Doulcet, A., Mouly, B., Osorio, C., Pince, J. M. (2003). Onshore-offshore structure of the northern Colombia accretionary complex. American Association of Petroleum Geologists, Search and Discovery article 90017.

2. Pindell, J., Kennan, L., Maresch, W. V., Stanek, K., Draper, G., Higgs, R. (2005). Plate-kinematics and crustal dynamics of circum-Caribbean arc-continent interactions: Tectonic controls on basin development in Proto-Caribbean margins. Special Papers-Geological Society of America, 394, 7.

3. Montes, C., Guzman, G., Bayona, G., Cardona, A., Valencia, V., Jaramillo, C. (2010). Clockwise rotation of the Santa Marta massif and simultaneous Paleogene to Neogene deformation of the Plato-San Jorge and Cesar-Ranchería basins. Journal of South American Earth Sciences, 29(4), 832-848.

4. van Benthem, S., Govers, R., Spakman, W., Wortel, R. (2013). Tectonic evolution and mantle structure of the Caribbean. Journal of Geophysical Research: Solid Earth, 118(6), 3019-3036.

5. Pennington, W. D. (1981). Subduction of the eastern Panama Basin and seismotectonics of northwestern South America. Journal of Geophysical Research: Solid Earth, 86(B11), 10753-10770.

6. Cortés, M., and Angelier, J., (2005), Current states of stress in the northern Andes as indicated by focal mechanisms of earthquakes: Tectonophysics, v. 403, no. 1-4, p. 29-58, doi: 24710.1016/j.tecto.2005.03.020

7. Kellog, J., Toto, E., and Cerón, J. (2005). Structure and tectonics of the Sinu-San Jacinto accretionary prism in northern Colombia. Memorias X Congreso Colombiano de Geología, Bogotá, 10p.

8. Egbue, O.; Kellogg, J. Pleistocene to Present North Andean “escape.” Tectonophysics 2010, 489 (1-4), 248-257 DOI: 10.1016/j.tecto.2010.04.021

9. Trenkamp R., J. Kellogg, J. Freymueller, H. Mora. (2002). Wide plate margin deformation, southern Central America and northwestern South America, CASA GPS observations. Journal of South American Earth Sciences, 15(2):157-171.

10. Cediel, F., Shaw, R. P., and Caceres, C. (2002). Tectonic assembly of the northern andean block. 815-848.

11. Bird, P. (2003). An updated digital model of plate boundaries. Geochemistry, Geophysics, Geosystems, 4(3).

12. Bayona, G.; Ochoa, F.; Cardona, I.; Jaramillo, A.; Montes, C.; Tchegliakova, N. Procesos Orogénicos Del Paleoceno Para La Cuenca De Ranchería (Guajira, Colombia) Y Áreas Adyacentes Definidos Por Análisis De Procedencia. Geología Colombiana 2007, 32, 26.

13. Leal-Mejía, H. (2011). Phanerozoic gold metallogeny in the colombian andes: A tectono-magmatic approach [ph. d. thesis]: Barcelona. Spain, Universitat de Barcelona.

14. Galindo, P. (2015). Transtension and transpression in an oblique subduction setting: evolution of the Bahia Basin, Colombian Caribbean margin (Doctoral dissertation, Imperial College London).

15. Galindo, P. A., \& Lonergan, L. (2020). Basin evolution and shale tectonics on an obliquely convergent margin: the Bahia Basin, offshore Colombian Caribbean. Tectonics, 39(3), e2019TC005787.

16. Taboada A., L.A. Rivera, A. Fuenzalida, A. Cisternas, H. Philip, H. Bijwaard, J. Olaya y C. Rivera. (2000). Geodynamics of the northern Andes: Subductions and intracontinental deformation (Colombia): Tectonics, 19(5):787-813

17. Audemard, F. E., Audemard, F. A. (2002). Structure of the Mérida Andes, Venezuela: relations with the South America-Caribbean geodynamic interaction. Tectonophysics, 345(1-4), 1-26.

18. Kennan, L. and Pindell, J. L. (2009). Dextral shear, terrane accretion and basin formation in the northern andes: best explained by interaction with a pacific-derived caribbean plate? Geological Society, London, Special Publications, 328(1):487-531.

19. Piraquive-Bermúdez, A. (2016). Structural Framework, deformation and exhumation of the Santa Marta Schists: accretion and deformational history of a Caribbean Terrane at the north of the Sierra Nevada de Santa Marta (Doctoral dissertation, Universidad Nacional de Colombia-Sede Bogotá)

20. Quintero-Ortiz, C. (2017). Tectónica Transpresiva en el Margen septentrional de la Serranía de Cosinas en la Alta Guajira (Colombia). PhD thesis, Universidad Nacional de Colombia-Sede Bogotá

21. Gómez, I., (2001). Structural Style and Evolution of the Cuisa Fault System, Guajira, Colombia, University of Houston, Houston, TX, 147p.

22. Mercado, M., (2003). Mapa Geológico del Departamento de La Guajira, Escala 1:250000. Memoria Explicativa, INGEOMINAS

23. Fairbridge, R. W. (1968): The encyclopaedia of geomorphology. Reinhold, New York, 1295.

24. Kusák, M., Krbcová, K., Križan, F., Kunc, J., Bilková, K., Barlík, P., Šilhan, Z., Eretová, V., Jančák, V., Jeníček, M., et al. (2017). Analysis of the relationship of automatically and manually extracted lineaments from dem and geologically 
mapped tectonic faults around the main ethiopian rift and the ethiopian highlands, ethiopia. AUC GEOGRAPHICA, 52(1):5-17

25. Scheidegger, A. E. (2004). Global morphotectonics. In Morphotectonics (pp.35-109). Springer, Berlin, Heidelberg.

26. Turcotte, R., Fortin, J.-P., Rousseau, A.N., Massicotte, S., Villeneuve, J.-P., (2000). Determination of the drainage structure of a watershed using a digital elevation model and a digital river and lake network. J. Hydrol. 240 (3-4), 225-242. http://dx.doi.org/10.1016/S0022-1694(00)00342-5

27. Terrizzano, C.M., Cortés, J.M., Zech, R., Morabito, E.G., (2014). Drainage anomalies as indicators of soft-linked deformation zones between neotectonic structural highs in the Precordillera, Central Andes of Argentina. Geomorphology 224, 1-15. http://dx.doi.org/10.1016/j.geomorph.2014.07.004.

28. Henao, J. L. N. (2015). Fotogeología práctica: fotogeología descriptiva e interpretativa con ejemplos de Colombia. Universidad de Caldas, Facultad de Ciencias Exactas y Naturales.

29. Radaideh, O. M., Grasemann, B., Melichar, R., and Mosar, J. (2016). Detection and analysis of morphotectonic features utilizing satellite remote sensing and gis: An example in sw jordan. Geomorphology, 275:58-79.

30. Das, S., Pardeshi, S. D., Kulkarni, P. P., Doke, A. (2018). Extraction of lineaments from different azimuth angles using geospatial techniques: a case study of Pravara basin, Maharashtra, India. Arabian Journal of Geosciences, 11(8), 160.

31. Prabhakaran, A. and Jawahar Raj, N. (2018). Mapping and analysis of tectonic lineaments of pachamalai hills, tamil nadu, india using geospatial technology. Geology, Ecology, and Landscapes, pages 1-23.

32. Kusák, M., Kropáček, J., and Vilimek, V. (2016). Analysis of the influence of tectonics on the evolution of valley networks based on srtm dem, jemma river basin, ethiopia. Geografia Fisica e Dinamica Quaternaria, 39(1):37-50.

33. Florinsky, I. (2016). Digital terrain analysis in soil science and geology. Academic Press.

34. Saadi, N.M., Abdel Zaher, M., El-Baz, F., Watanabe, K., (2011). Integrated remote sensing data utilization for investigating structural and tectonic history of the Ghadames Basin, Libya. Int. J. Appl. Earth Obs. Geoinf. 13 (5), 778-791. http://dx.doi.org/10.1016/j.jag.2011.05.016.

35. Launeau, P. and Robin, P. Y. F. (1996). Fabric analysis using the intercept method. Tectonophysics 267, 91-119.

36. Gabrielsen, R.H., Braathen, A., Dehls, J., Roberts, D., (2002). Tectonic lineaments of Norway.Nor. J. Geol. 82, 153-174.

37. Zernitz, E.R., (1932). Drainage patterns and their significance. J. Geol. 40 (6), $498-521$. http://dx.doi.org/10.1086/623976.

38. Zhang, W., Montgomery, D. R. (1994). Digital elevation model grid size, landscape representation, and hydrologic simulations. Water resources research, 30(4), 1019-1028.

39. Mack, G. H., Leeder, M. R. (1999). Climatic and tectonic controls on alluvial-fan and axial-fluvial sedimentation in the Plio-Pleistocene Palomas half graben, southern Rio Grande Rift. Journal of Sedimentary Research, 69(3), 635-652.

40. Zaprowski, B.J., Evenson, E.B., Pazzaglia, F.J., Epstein, J.B., (2001). Knickzone propagation in the Black Hills and northern High Plains: a different perspective on the late Cenozoic exhumation of the Laramide Rocky Mountains. Geol. Soc. Am. 29 (6), 547-550. http://dx.doi.org/10.1130/0091 -7613(2001)029b0547:KPITBHN2.0.CO;2 (Wyoming, USA).

41. Ciotoli G., Della Seta M., Del Monte M., Fredi P., Lombardi S., Palmieri E.L. Pugliese F. (2003) - Morphological and geochemical evidence of neotectonics in the volcanic area of Monti Vulsini (Latium, Italy). Quaternary International 101, 103-113.

42. Ribolini, A. and Spagnolo, M. (2007). Drainage network geometry versus tectonics in the argentera massif (french-italian alps). Geomorphology, 93(3- 4):253-266.

43. Hung, L., Batelaan, O., San, D., and De Smedt, F. (2004). Lineament analysis for the groundwater in karst fractured rocks in the suoimuoi karst catchment. In Trans-Karst 2004, International Transdiciplinary Conference on Development and Conservation of Karst Regions, pages 92-96. Research Institute of Geology and Mineral Resources (RIGMR).

44. Sarp, G. (2005). Lineament analysis from satellite images, north-west of ankara. Master of Science Dissertation, School of Natural and Applied Science of Middle East Technical University.

45. Argyriou, A., (2012). A Methodology for the Rapid Identification of Neotectonic Features Using Geographical Information Systems and Remote Sensing: A Case Study From Western Crete, Greece (PhD Thesis) School of Earth and Environmental Sciences, University of Portsmouth, Portsmouth, United Kingdom.

85. Schillaci, C., Braun, A., Kropáček, J. (2015). 2.4. 2. Terrain analysis and landform recognition. Geomorphological techniques, 2, 1-18. 
47. Mwaniki, M. W., Moeller, M. S., Schellmann, G. (2015). A comparison of Landsat 8 (OLI) and Landsat 7 (ETM+) in mapping geology and visualising lineaments: A case study of central region Kenya. International Archives of the Photogrammetry, Remote Sensing Spatial Information Sciences.

48. Kamel, M., Youssef, M., Hassan, M., Bagash, F. (2016). Utilization of ETM+ Landsat data in geologic mapping of wadi Ghadir-Gabal Zabara area, Central Eastern Desert, Egypt. The Egyptian Journal of Remote Sensing and Space Science, 19(2), 343-360.

49. Kocal, A., Duzgun, H., and Karpuz, C. (2007). An accuracy assessment methodology for the remotely sensed discontinuities: a case study in andesite quarry area, turkey. International Journal of Remote Sensing, 28(17):3915-3936.

50. Abdullah, A., Akhir, J.M., Abdullah, I., (2010). Automatic mapping of lineaments using shaded relief images derived from digital elevation model (DEMs) in the Maran - SungiLembing area, Malaysia. Electron. J. Geotech. Eng. 15 (J), 949-957.

51. Muhammad, I. A. A. (2017). Lineament Extraction Using Remote Sensing Data mid Iraq. Journal of University of Babylon, 25(2), 597-582.

52. IGAC. (1996). Diccionario Geográfico de Colombia, $3^{a}$ ed. (revisada y aumentada). 1:288-294. Santa Fe de Bogotá.

53. Barrero, D., Pardo, A., Vargas, C. Y Martinez, J., (2007). Colombian sedimentary basins: Nomenclature, boundaries and petroleum geology, a new proposal. ANH, Bogotá.

54. Pindell, J. L. (1993). Evolution of the gulf of mexico and the caribbean. Caribbean geology: an introduction, pages 13-39

55. Toussaint, J. (1996). Evolución geológica de colombia, cretácico. Universidad Nacional de Colombia. Medellín, 142.

56. Montes, C., Hatcher Jr, R. D., and Restrepo-Pace, P. A. (2005). Tectonic reconstruction of the northern andean blocks: Oblique convergence and rotations derived from the kinematics of the piedras-girardot area, colombia. Tectonophysics, 399(1-4):221-250.

57. Weber, M., Cardona, A., Paniagua, F., Cordani, U., Sepúlveda, L., and Wilson, R. (2009). The cabo de la vela mafic-ultramafic complex, northeastern colombian caribbean region: a record of multistage evolution of a late cretaceous intra-oceanic arc. Geological Society, London, Special Publications, 328(1):549-568.

58. Cediel, F. and Caceres, C., (2000), Geological Map of Colombia: Geotec, Ltd., Bogotá, 3rd Edition, digital format with legend and tectono-stratigraphic chart.

59. Vinasco, C., (2004), Evolução crustal e história tectônica dos granitoides Permo- Triassicos dos Andes do Norte: M.Sc. thesis, Sao Paulo, Brasil, Universidade de Sao Paulo, 183 p.

60. Vinasco, C.J., Cordani, U.G., González, H., Weber, M. and Pelaez, C., (2006), Geochronological, isotopic, and geochemical data from Permo-Triassic granitic gneisses and granitoids of the Colombian Central Andes: Journal of South American Earth Sciences, v. 21,p. 355-371.

61. Boschman, L. M., van Hinsbergen, D. J., Torsvik, T. H., Spakman, W., \& Pindell, J. L. (2014). Kinematic reconstruction of the Caribbean region since the Early Jurassic. Earth-Science Reviews, 138, 102-136.

62. Kellogg, J. (1984). Cenozoic tectonic history of the Sierra de Perijá, Venezuela- Colombia, and adjacent basins. Geological Society of American Memoirs, 162: 239-262

63. Caro, M., and Spratt, D. (2003). Tectonic evolution of the San Jacinto fold belt, NW Colombia. CSEG Recorder, February, pp. 37-43.

64. Marin, F.M., (2010). Biodiversidad del margen continental del Caribe Colombiano. Santa Marta: INVEMAR.

65. MacDonald, W.D., (1964). Geology of the Serranía de Macuira area, Guajira Peninsula, Colombia. PhD Thesis. Princeton University.

66. Villagómez, D., Spikings, R., Mora, A., Guzmán, G., Ojeda, G., Cortés, E., Van Der Lelij, R. (2011). Vertical tectonics at a continental crust-oceanic plateau plate boundary zone: Fission track thermochronology of the Sierra Nevada de Santa Marta, Colombia. Tectonics, 30(4).

67. Molina, A. C., Cordani, U. G., MacDonald, W. D. (2006). Tectonic correlations of pre-Mesozoic crust from the northern termination of the Colombian Andes, Caribbean region. Journal of South American Earth Sciences, 21(4), 337-354.

68. Cardona, A., Weber, M., Valencia, V., Bustamante, C., Montes, C., Cordani, U., Muñoz, C. M. (2014). Geochronology and geochemistry of the Parashi granitoid, NE Colombia: Tectonic implication of short-lived Early Eocene plutonism along the SE Caribbean margin. Journal of South American Earth Sciences, 50, 75-92.

69. Alvarez, W. (1967). Geology of the Simarua and Carpintero areas, Guajira Peninsula, Colombia [Ph. D. dissert.]: Princeton Univ., 168 p. 1971, Fragmented Andean belt of northern Colombia. Caribbean geophysical, tectonic, and petrologic studies: Geol. Soc. America Mem, 130, 77-96. 
70. Rodríguez, G. and Londoño, A. (2002). Mapa geológico del departamento de la guajira. Ingeominas, Bogotá, 206p.

71. Weber, M., Cardona, A., Valencia, V., García-Casco, A., Tobón, M., Zapata, S. (2010). U/Pb detrital zircon provenance from Late Cretaceous metamorphic units of the Guajira Peninsula, Colombia: tectonic implications on the collision between the Caribbean arc and the South American margin. Journal of South American Earth Sciences, 29(4), 805-816.

72. Weber, M., Cardona, A., Valencia, V., Altenberger, U., López-Martinez, M., Tobón, M., Zapata, S., Zapata, G., and Concha, A. E. (2011). Geochemistry and geochronology of the guajira eclogites, northern colombia: evidence of a metamorphosed primitive cretaceous caribbean island-arc. Geologica Acta: an international earth science journal, 9(3-4).

73. Romero, J. (2006). Estudio sedimentológico de la plataforma continental de la guajira entre los 10 y $50 \mathrm{~m}$ de profundidad. Trabajo de grado para optar por el título de Geólogo de la Universidad Nacional de Colombia, sede Bogotá, con la colaboración de INVEMAR. Bogotá.

74. Hermelin, M. and Posada, B. (2015). Landscapes and Landforms of Colombia. Springer

75. González, M. G. G., Umaña, R. M., Guevara, L. E. C. (2010). RECONSTRUCCIÓN DE LA HISTORIA PALEOTERMAL DE LA SUBCUENCA DE LA BAJA GUAJIRA, COLOMBIA. Boletín de Geología, 32(2).

76. Cardona, A., Weber, M., Wilson, R., Cordani, U., Muñoz, C. M., Paniagua, F., (2007). Evolución tectono-magmática de las rocas maficas-ultramáficas del Cabo de La Vela y el Stock de Parashi, Península de la Guajira: registro de la evolución orogénica Cretácica-Eocena del norte de Suramérica y el Caribe. XI Congreso Colombiano de Geologia, Bucaramanga, Agosto 14-17

77. Renz, O. (1960). Geología de la parte sureste de la Península de La Guajira (República de Colombia). In Congreso Geológico Venezolano, Venezuela.

78. Rollins, J. F. (1965). Stratigraphy and structure of the Goajira Peninsula, northwestern Venezuela and Northeastern Colombia.

79. Vence, E. (2008). Subsurface structure, stratigraphy, and regional tectonic controls of the Guajíra margin of northern Colombia. University of Texas at Austin.

80. Pérez-Consuegra, N., Parra, M., Jaramillo, C., Silvestro, D., Echeverri, S., Montes, C., ... Escobar, J. (2018). Provenance analysis of the Pliocene Ware Formation in the Guajira Peninsula, northern Colombia: Paleodrainage implications. Journal of South American Earth Sciences, 81, 66-77.

81. Lozano, E., Zamora, N.(2014) COMPILACIÓN DE LA CUENCA DE LA GUAJIRA. Bogotá: SGC and MinMinas.(p. 16).

82. Rabus, B., Eineder, M., Roth, A., and Bamler, R. (2003). The shuttle radartopography mission—a new class of digital elevation models acquired by spaceborne radar. ISPRS journal of photogrammetry and remote sensing, 57(4):241- 262.

83. Farr, T. G. and Kobrick, M. (2000). Shuttle radar topography mission produces a wealth of data. Eos, Transactions American Geophysical Union, 81(48):583-585.

84. Wang, L. and Liu, H. (2006). An efficient method for identifying and filling surface depressions in digital elevation models for hydrologic analysis and modelling. International Journal of Geographical Information Science, 20(2):193-213.

85. Schillaci, C., Braun, A. (2015). Terrain analysis and landform recognition.

86. Deffontaines, B., Chotin, P., Brahim, L. A., Rozanov, M. (1992). Investigation of active faults in Morocco using morphometric methods and drainage pattern analysis. Geologische Rundschau, 81(1), 199-210.

87. Mogaji, K.A., Aboyeji, O.S., Omosuyi, G.O., (2011). Mapping of lineaments for groundwater targeting in the basement complex region of Ondo State, Nigeria, using remote sensing and geographic information system (GIS) techniques. Int. J. Water Resour. Environ.Eng. 3 (7), 150-160.

88. Ribolini, A., Spagnolo, M. (2008). Drainage network geometry versus tectonics in the Argentera Massif (French-Italian Alps). Geomorphology, 93(3-4), 253-266.

89. Krř́žek, M. and Kusák, M. (2014). Variability of the morphometric characteristics of valley networks caused by variations in a scale. AUC GEOGRAPHICA, 49(1).

90. Jawahar Raj, N., Prabhakaran, A., and Muthukrishnan, A. (2017). Extraction and analysis of geological lineaments of kolli hills, tamil nadu: a study using remote sensing and gis. Arabian Journal of Geosciences, 10(8):195.

91. Mark, R.K., (1992). A multidirectional, oblique-weighted, shaded-relief image of the Island of Hawaii. U.S. Geological Survey Open-file Report 92-422 (Version 1.0) Available only at http://pubs.usgs.gov/of/1992/of92-422/

92. Geomatica, I. I., OrthoEngine, G. (2004). Geomatica I.

93. Suzen,M.L., and Toprak, V., (1998). Filtering of satellite images in geological lineament analyses:an application to a fault zone in Central Turkey. Int. J. Remote Sens. 19 (6),1101-1114. http://dx.doi.org/10.1080/014311698215621 
94. Greenbaum, D. (1985). Review of remote sensing applications to groundwater exploration in basement and regolith.

109. Kumar, R. and Reddy, T. (1991). Digital analysis of lineaments—atest study on south india. Computers Geosciences, 17(4):549-559.

96. Eliet, P. P., Gawthorpe, R. L. (1995). Drainage development and sediment supply within rifts, examples from the Sperchios basin, central Greece. Journal of the Geological Society, 152(5), 883-893.

97. Schlunegger, F., Hinderer, M., (2001). Crustal uplift in the Alps: why drainage pattern matters. Terra Nova 13 (6), 425-432.

98. Van der Beek, P., Champel, B., Mugnier, J.L., (2002). Control of detachment dip on drainage development in regions of active faultpropagation folding. Geology 30, 471-474.

99. Delcaillau, B., Carozza, J.M., Laville, E., (2006). Recent fold growth and drainage development: the Janauri and Chandigarh anticlines in the Siwalik foothills, northwest India. Geomorphology 76, 241-256

100. Shahzad, F., Mahmood, S. A., and Gloaguen, R. (2009). Drainage network and lineament analysis: an approach for potwar plateau (northern pakistan). Journal of Mountain Science, 6(1):14.

101. Bahrami, S., (2013). Analyzing the drainage system anomaly of Zagros basins: implications for active tectonics. Tectonophysics 608, 914-928. http://dx.doi.org/10.1016/j.tecto.2013.07.026.

102. ESRI (2011). Arc hydro geoprocessing tools v. 2.0 - tutorial. environmental systems research institute, redlands, california, united states. GEOSIGMA AB. Report, 1:251.

103. Hack, J. T. (1973). Stream-profile analysis and stream-gradient index. Journal of Research of the us Geological Survey, $1(4), 421-429$.

104. Clark, M. K., Schoenbohm, L. M., Royden, L. H., Whipple, K. X., Burchfiel, B. C., Zhang, X., ... Chen, L. (2004). Surface uplift, tectonics, and erosion of eastern Tibet from large-scale drainage patterns. Tectonics, 23(1).

105. Shahzad, F., Gloaguen, R. (2011). TecDEM: A MATLAB based toolbox for tectonic geomorphology, Part 1: Drainage network preprocessing and stream profile analysis. Computers Geosciences, 37(2), 250-260.

140. Hayakawa, Y. S., Oguchi, T. (2006). DEM-based identification of fluvial knickzones and its application to Japanese mountain rivers. Geomorphology, 78(1-2), 90-106.

107. Duvall, A., Kirby, E., Burbank, D. (2004). Tectonic and lithologic controls on bedrock channel profiles and processes in coastal California. Journal of Geophysical Research: Earth Surface, 109(F3).

108. Montgomery, D. R. (1994). Road surface drainage, channel initiation, and slope instability. Water Resources Research, 30(6), 1925-1932.

109. Kumar, R. and Reddy, T. (1991). Digital analysis of lineaments—atest study on south india. Computers Geosciences, 17(4):549-559.

110. Hung, L. Q., Batelaan, O., De Smedt, F. (2005). Lineament extraction and analysis, comparison of LANDSAT ETM and ASTER imagery. Case study: Suoimuoi tropical karst catchment, Vietnam. In Remote sensing for environmental monitoring, GIS applications, and geology V (Vol. 5983, p. 59830T). International Society for Optics and Photonics.

111. Edet, A., Okereke, C., Teme, S., and Esu, E. (1998). Application of remotesensing data to groundwater exploration: a case study of the cross river state, southeastern nigeria. Hydrogeology Journal, 6(3):394-404.

112. Chandrasekhar, P., Martha, T. R., Venkateswarlu, N., Subramanian, S., and Kamaraju, M. (2011). Regional geological studies over parts of deccan syneclise using remote sensing and geophysical data for understanding hydrocarbon prospects. Current Science, pages 95-99.

113. Masoud, A. A. and Koike, K. (2011). Auto-detection and integration of tectonically significant lineaments from srtm dem and remotely-sensed geophysical data. ISPRS journal of Photogrammetry and Remote sensing, 66(6):818-832.

114. Sener, E., Davraz, A., and Ozcelik, M. (2005). An integration of gis and remote sensing in groundwater investigations: a case study in burdur, turkey. Hydrogeology Journal, 13(5-6):826-834.

115. Ahmed, S. et al. (2014). Lineament extraction from southern chitradurga schist belt using landsat tm, astergdem and geomatics techniques. International Journal of Computer Applications, 93(12).

116. Jawahar Raj, N., Prabhakaran, A., and Muthukrishnan, A. (2017). Extraction and analysis of geological lineaments of kolli hills, tamil nadu: a study using remote sensing and gis. Arabian Journal of Geosciences, 10(8):195.

117. Nugroho, U. C. and Tjahjaningsih, A. (2017). Lineament density information extraction using dem srtm data to predict the mineral potential zones. International Journal of Remote Sensing and Earth Sciences (IJReSES), 13(1):67-74

118. Casas, A. M., Cortes, A. L., Maestro, A., Soriano, M. A., Riaguas, A., and Bernal, J. (2000). Lindens: a program for lineament length and density analysis. Computers Geosciences, 26(9-10):1011-1022.

119. Prabu, P., Rajagopalan, B. (2013). Mapping of lineaments for groundwater targeting and sustainable water resource management in hard rock hydrogeological environment using RS-GIS. Clim Change Reg Local Responses, 10, 235-247. 
120. Sepulveda, L. (2003). Ultramafitas del Cabo de la Vela y rocas gabróicas asociadas. PhD thesis, Tesis de grado (inédita), Facultad de Minas, Universidad Nacional de Colombia, Sede Medellín.

121. Lewis, J. F., Draper, G., Fernández, J. P., Espaillat, J., Jiménez, J. (2006). Ophiolite-related ultramafic rocks (serpentinites) in the Caribbean region: a review of their occurrence, composition, origin, emplacement and Ni-laterite soil formation. Geologica Acta, 4(1-2), 237-264.

122. Bustamante, C., Cardona, A., Saldarriaga, M., Garía-Casco, A., Valencia, V., and Weber, M. (2009). Metamorphism of the greenschists and amphibolites from the santa marta schists, sierra nevada de santa marta (colombia): Arccontinent collision between the caribbean and the

123. Lockwood, J. P. (1965). Geology of the Serrania de Jarara area, Guajira peninsula, Colombia. PhD thesis, Princeton University.

124. Lugo, J., and P. Mann, 1995, Jurassic-Eocene tectonic evolution of Maracaibo basin, Venezuela, in A. J. Tankard, R. Suárez S., and H. J.Welsink, Petroleum basins of South America: AAPG Memoir 62, p. 699-725.

125. Christeson, G. L., Mann, P., Escalona, A., Aitken, T. J. (2008). Crustal structure of the Caribbean-northeastern South America arc-continent collision zone. Journal of Geophysical Research: Solid Earth, 113(B).

126. Scholz, C. H. (1977). Transform fault systems of California and New Zealand: similarities in their tectonic and seismic styles. Journal of the Geological Society, 133(3), 215-228.

127. Katz, Y., Weinberger, R., Aydin, A. (2004). Geometry and kinematic evolution of Riedel shear structures, Capitol Reef National Park, Utah. Journal of structural geology, 26(3), 491-501.

128. Davis, G. H., Bump, A. P., Garcia, P. E., Ahlgren, S. G. (2000). Conjugate Riedel deformation band shear zones. Journal of Structural Geology, 22(2), 169-190.

129. Riedel, W. (1929). Zur Mechanik geologischer Brucherscheinungen ein Beitrag zum Problem der Fiederspatten. Zentbl. Miner. Geol. Palaont. Abt., 354-368.

130. Tchalenko, J. S. (1970). Similarities between shear zones of different magnitudes. Geological Society of America Bulletin, 81(6), 1625-1640.

131. Strahler, A. N. (1952). Hypsometric (area-altitude) analysis of erosional topography. Geological Society of America Bulletin, 63(11):1117-1142.

132. Strahler, A. N. (1957). Quantitative analysis of watershed geomorphology. Eos, Transactions American Geophysical Union, 38(6):913-920.

133. Horton, R. E. (1932). Drainage-basin characteristics. Eos, transactions american geophysical union, 13(1), 350-361.

134. Argialas, D., Lyon, J., and Mintzer, O. (1988). Quantitative description and classification of drainage patterns. PHOTOGRAMMETRIC ENGINEERING AND REMOTE SENSING, 54(4):505-509.

135. Howard, J. D., Lohrengel, C. F. (1969). Large non-tectonic deformational structures from upper cretaceous rocks of Utah. Journal of Sedimentary Research, 39(3), 1032-1039.

136. Schumm, S. A., Schumm, S. A., Dumont, J. F., and Holbrook, J. M. (2002). Active tectonics and alluvial rivers. Cambridge University Press.

137. Twidale, C. R. (2004). River patterns and their meaning. Earth-Science Reviews, 67(3-4), 159-218.

138. Ouchi, S. (1985). Response of alluvial rivers to slow active tectonic movement. Geological Society of America Bulletin, 96(4), 504-515.

139. Miller, J. R. (1991). Controls on channel form along bedrock-influenced alluvial streams in south-central Indiana. Physical Geography, 12(2), 167-186.

140. Hayakawa, Y. S., Oguchi, T. (2006). DEM-based identification of fluvial knickzones and its application to Japanese mountain rivers. Geomorphology, 78(1-2), 90-106.

141. Hernández, R., Ramírez, V., and Reyes, J. (2003). Evolución geohistórica de las cuencas del norte de colombia. In 8th Simposio Bolivariano-Exploracion Petrolera en las Cuencas Subandinas.

Sample Availability: Samples of the compounds ...... are available from the authors. 